
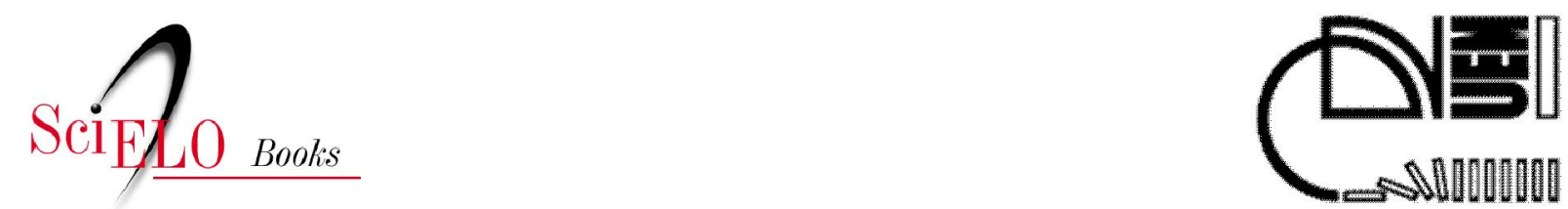

\title{
As políticas públicas para a educação infantil e a dinâmica do capitalismo
}

\author{
Jani Alves da Silva Moreira \\ Angela Mara de Barros Lara
}

\section{SciELO Books / SciELO Livros / SciELO Libros}

MOREIRA, JAS., and LARA, AMB. Políticas públicas para a educação infantil no Brasil (19902001) [online]. Maringá: Eduem, 2012. As políticas públicas para a educação infantil e a dinâmica do capitalismo. pp. 75-162. ISBN 978-85-7628-585-4. Available from SciELO Books $<$ http://books.scielo.org $>$.

\section{(1) (1) @(9)}

All the contents of this chapter, except where otherwise noted, is licensed under a Creative Commons Attribution-Non Commercial-ShareAlike 3.0 Unported.

Todo o conteúdo deste capítulo, exceto quando houver ressalva, é publicado sob a licença Creative Commons Atribuição Uso Não Comercial - Partilha nos Mesmos Termos 3.0 Não adaptada.

Todo el contenido de este capítulo, excepto donde se indique lo contrario, está bajo licencia de la licencia Creative Commons Reconocimento-NoComercial-CompartirIgual 3.0 Unported. 


\section{AS POLÍTICAS PÚBLICAS PARA A EDUCAÇÃO INFANTIL E A DINÂMICA DO CAPITALISMO}

O objetivo desta parte é analisar as políticas públicas para a Educação Infantil implementadas no Brasil a partir da década de 1990. O percurso até aqui esteve pautado na compreensão do contexto macroeconômico da sociedade, na dinâmica da mundialização do capital. $O$ procedimento a ser realizado nesta parte é compreender as políticas para a Educação Infantil inseridas no contexto das reformas educacionais e no âmbito político-econômico-social a partir da década de 1990. Nas análises aqui desenvolvidas foram utilizados três procedimentos metodológicos: 1)compreensão dos pressupostos históricos da Educação Infantil no Brasil e da dinâmica do capitalismo; 2)- análise das políticas propostas para o atendimento à infância e à Educação Infantil nos documentos dos organismos internacionais; e 3)- compreensão das políticas públicas para a infância e seus pressupostos nos documentos oficiais do MEC. 
Políticas públicas para a Educaçäo Infantil no Brasil (1990-2001)

\subsection{PRESSUPOSTOS HISTÓRICOS DA EDUCAÇÃO INFANTIL}

Para entender o percurso e os significados que resultaram no reconhecimento da Educação Infantil como a primeira etapa da Educação Básica e das implicações políticas decorrentes desse processo, faz-se necessário compreender o contexto que viabilizou ações e propostas para a Educação infantil não mais de cunho compensatório e assistencial, mas sim, o oposto de assistência, ou seja, propostas e ações que integram um projeto educacional. Este processo é relevante, pois,

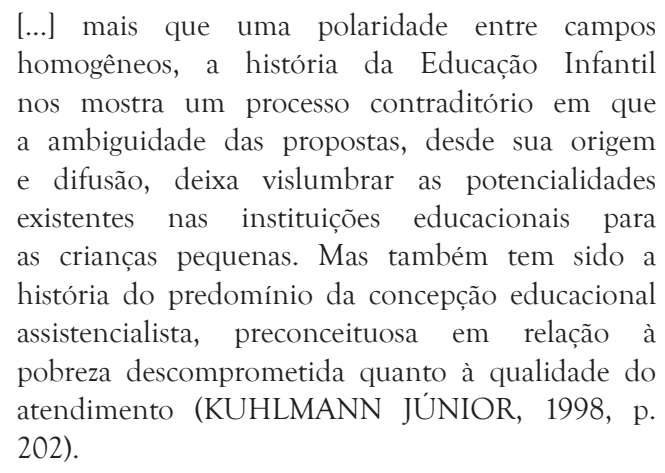

Compreender a criança historicamente exige um estudo que, além de ser dispendioso, requer cuidado quanto ao enfoque metodológico. Kuhlmann Júnior (1998) apresenta duas abordagens já utilizadas em pesquisas sobre a infância que não possibilitam a compreensão da totalidade histórica. A primeira delas faz referência à obra de Philippe Ariè ${ }^{53}$ sobre a "História da

53 Philippe Ariés (1986), em seu livro "História Social da Criança e da Família”, analisa o conceito de criança através da iconografia. Ele menciona que na Idade Média o conceito de Infância não existia, ou seja, a consciência de uma particularidade infantil que distingue a criança do adulto. 
Criança e da Família”, que tem como enfoque os comportamentos e mentalidades, identifica apenas parte da realidade. Outra abordagem é a psico-histórica de Lloy De Mause ${ }^{54}$, que seria uma aplicação da psicanálise e da psicogenética na compreensão da história da infância num enfoque contrário ao materialismo histórico

No campo de pesquisa da história da infância e sua concepção encontram-se divergências e linhas diferentes para interpretar o que é ser criança e como as sociedades concebem a criança enquanto ser histórico. Torna-se relevante realizar estudos sobre a história da infância que se proponham a estudá-la em uma visão pautada no referencial histórico, na realidade social da sociedade capitalista em sua forma de engendrar o homem e suas relações sociais, entre elas a própria educação.

Estudar os pressupostos históricos da Educação Infantil é um procedimento necessário para a compreensão das políticas educacionais. Sanfelice (2004, p. 98), ao abordar a complexidade da situação teórico-metodológica da produção de pesquisas realizadas no campo da histórica da educação, afirma:

\footnotetext{
Fontes e história das políticas educacionais, para mim, é um tema recorte da história da educação, por sua vez recorte da história. Recorte apenas oportuno no sentido de privilegiar a análise de um objeto específico e não no sentido de isolamento do mesmo objeto $[. .$.$] o recorte não tem o sentido de isolar o$ objeto específico a ser estudado.
}

Diante dessas considerações, justifica-se a necessidade de compreender os pressupostos históricos da Educação Infantil

54 Coordenador do Instituto de psico-história sediado em Nova Iorque. 
Políticas públicas para a Educaçäo Infantil no Brasil (1990-2001)

no Brasil tendo-se como recorte histórico o final do século XIX na maneira como este período foi entendido na primeira parte desta pesquisa. Os estudos de Rizzini (1997) referentes às raízes históricas das políticas públicas para a infância no Brasil demonstram que no período do capitalismo internacional a criança foi o fulcro para o empreendimento da moralização da pobreza, pois as condições dos pobres eram interpretadas como um problema de ordem moral e social. Para a autora,

\footnotetext{
Garantir a paz e a saúde do corpo social é entendido como uma obrigação do Estado. A criança será o fulcro deste empreendimento, pois constituirá um dos principais instrumentos de intervenção do Estado na família, atingindo os transgressores da ordem no nível mais individual e privado possível (RIZZINI, 1997, p. 26-27).
}

Nesse período o Brasil vivia um momento que fazia eco às transmutações mundiais, com "[...] a realização de seu anseio emancipatório, ou seja, da busca de materialização de sua nacionalidade, de uma identidade nacional. Assim, os tempos eram de mudanças, acreditava-se na possibilidade de reformar o Brasil” (RIZZINI, 1997, p. 27).

Rizzini (1997) argumenta que, em meio a essas mudanças econômicas, as políticas públicas para a criança tinham a perspectiva de moldá-la de acordo com o projeto que conduziria o Brasil ao seu ideal de Nação. Via-se a criança não mais como preocupação do âmbito privado da família e da Igreja, mas como uma questão de cunho social, de competência administrativa do Estado. Por isso, no início do século XX, a preocupação com a infância enquanto problema social refletia-se na preocupação com o futuro do país, pois se atribuía à infância um valor 
PARTE II - AS POLÍTICAS PÚBLICAS PARA A EDUCAÇÃO INFANTIL...

econômico de mercado, como comprova o discurso do Senador Lopes Trovão ${ }^{55}$ :

[...] Temos uma pátria a reconstruir, uma nação a firmar, um povo a fazer [...] e para empreender essa tarefa, que elemento mais dúctil e moldável a trabalhar do que a infância! São chegados os tempos, preconiza o Senador, de prepararmos na infância a célula de uma mocidade melhor, a gênesis de uma humanidade mais perfeita (TROVÃO, 1896 apud RIZZINI, 1997, p. 31).

Nas três primeiras décadas de instauração da República a discussão sobre a infância no Brasil foi marcada pela difusão do higienismo, ${ }^{56}$ como resultado da expressiva produção do conhecimento especializado acerca da infância. Afirma Rizzini (1997, p. 137): "[...] parece crucial analisar neste ponto a dimensão política que fez despertar particular interesse pela infância, pois encontrava afinidade com o projeto civilizatório que se desenhava o país”. Ao compreender esse projeto civilizatório, tem-se como aspecto desencadeador que "[... a responsabilidade do Estado para com os pobres passou a ser parâmetro utilizado como prova de civilização, e o fato natural tornou-se problema social” (KUHLMANN JÚNIOR, 1998, p. 60).

55 Rizzini (1997, p. 56) apresenta o senador Lopes Trovão e comenta que este “[...] nasceu na cidade de Angra dos Reis, Rio de Janeiro, em 23 de maio de 1848. Doutorou-se em medicina pela Faculdade do Rio de janeiro em 1875, declarando-se adepto das ideias republicanas. Destacou-se em sua postura crítica ao regime monárquico, participando ativamente do movimento contra o mesmo. Depois de aclamada a República, foi eleito Deputado ao Congresso Federal. Em 1895, elegeu-se Senador. Publicou livros sobre a medicina e história, bem como diversos artigos na imprensa (Gazeta da Tarde, O Combate) em defesa de suas ideias políticas. Dizia-se um defensor daqueles que não tinham lugar na sociedade, os pobres, as prostitutas, os menores."

56 O movimento higienista direcionado à infância, o "higienismo infantil", foi abraçado por médicos brasileiros no final do século XIX. A ideia era a de investir na infância, através de atuação com o caráter científico - filantrópico da medicina, sobre a família, ensinando-lhes as noções básicas de higiene e saúde em sentido físico e moral (RIZZINI, 1997, p.176). 
Políticas públicas para a Educaçäo Infantil no Brasil (1990-2001)

No higienismo havia uma lógica de pensamento com o viés ideológico, tendo-se como projeto político a transformação do Brasil em uma nação civilizada, e para isso era primordial uma ação efetiva sobre a infância e a educação.

No contexto do imperialismo e da partilha do mundo praticamente consolidada instaurava-se um processo de conflitos entre as potências. As transformações nos âmbitos social, cultural, político e econômico foram impressionantemente rápidas e se deram em uma época de crise do capitalismo, inaugurada pela Primeira Guerra Mundial (1914-1918) e em seguida, marcada pela crise do Pós-Guerra (1920-1923), pela Revolução Russa (1917), pela crise econômica mundial de 1929 e pela Segunda Guerra Mundial (1939-1945). Em se tratando do Brasil e da América Latina, esse período significou um abalo, pelo recuo do capital inglês e a penetração do capital imperialista norteamericano.

Kuhlmann Júnior (2000) observa que as creches, jardins de infância e escolas maternais surgiram na segunda metade do século XIX. A grande expansão das relações internacionais nesse período levou à difusão das instituições de atendimento à infância, as quais chegaram ao Brasil na década de 1870. Com a Lei do Ventre livre ${ }^{57}$ (1871), a mulher pobre, sem trabalho, precisava urgentemente inserir-se no mercado de trabalho industrial, ficando seus filhos ao cuidado e amparo não mais dela, que, por necessidade básica, deixou de ser a presença única e exclusiva do lar. Muitas famílias decidiram abandonar seus

57 A Lei do Ventre Livre, composta por dez artigos, foi promulgada em 28 de setembro de 1871 pelo governo conservador do Visconde de Rio Branco. De poucos efeitos práticos, essa lei garantia a liberdade dos filhos de escravos, mas deixava-os sob tutela dos senhores até os 21 anos de idade. 
PARTE II - AS POLÍTICAS PÚBLICAS PARA A EDUCAÇÃO INFANTIL...

filhos nas Casas de Expostos $^{58}$. Sobre a criação das instituições pré-escolares, o autor afirma:
As instituições pré-escolares foram difundidas internacionalmente a partir da segunda metade do século XIX, como parte de um conjunto de medidas que conformam uma nova concepção assistencial, a assistência científica, abarcando aspectos como a alimentação e habitação dos trabalhadores e dos pobres [...] A grande marca dessas instituições, então foi a sua postulação como novidade, como propostas modernas, científicas - palavras utilizadas fartamente nessa época de exaltação do progresso e da indústria (KUHLMANN JÚNIOR, 1998, p. 81-82).

Essas primeiras instituições assistencialistas (1899-1922), segundo o autor, desempenharam o papel de cuidar das crianças como um antídoto para resolver a situação da sociedade, que precisava caminhar na ordem e no progresso, e assim formaram uma nova concepção, denominada assistência científica, por atenderem às necessidades de alimentação, saúde e habitação dos filhos dos trabalhadores e dos pobres.

Paralelamente a essa situação, o setor privado da educação pré-escolar, com interesse em legitimar-se, toma emprestado o termo pedagógico para a propaganda mercadológica e propõe os

58 As Casas de Expostos recebiam os bebês abandonados nas "rodas" - cilindros de madeira que permitiam o anonimato de quem ali deixasse a criança - para depois encaminhá-las às amas, que a criariam até a idade de ingressarem em internatos. Foram criadas por Romão Duarte em 1739, para abrigar "almas inocentes" que tivessem sido abandonadas, enjeitadas ou desamparadas. Eram também chamadas de "Casas dos Enjeitados" (KRAMER, 1987, p. 52). Rizzini (1997, p.181) descreve que essas instituições espalharam-se pelos países católicos, sendo implantadas no Brasil na década de 1730, através da Santa Casa de Misericórdia. Por mais de 150 anos os asilos de expostos com suas rodas cumpriram seu papel de abrigar os enjeitados da sociedade. 
Políticas públicas para a Educaçäo Infantil no Brasil (1990-2001)

jardins de infância ${ }^{59}$, de orientação froebeliana ${ }^{60}$, para os filhos da elite. Verifica-se que nesse período houve o engajamento de diversos setores sociais no atendimento à Educação Infantil.

Outro aspecto que marcou o início da criação das instituições infantis na década de 1870 foi a influência médico-higienista nas questões educacionais. A cooperação internacional para prevenção de doenças passou a ser assunto da maior importância, influenciando a educação popular com medidas preventivas e inspeção médico-escolar. $\mathrm{O}$ grande tema associado à assistência à infância era a mortalidade infantil.

As propostas consistiam do projeto geral de saneamento e de puericultura como forma de divulgar os cuidados com a higiene infantil. A puericultura era considerada como a ciência da família e conduzida com a colaboração confiante da mãe e do médico, do amor materno esclarecido pela ciência. Além disso, também era entendida como a ciência que tem por fim pesquisar os conhecimentos relativos à reprodução e à conservação da espécie humana. Neste sentido, a puericultura desdobrava-se em uma perspectiva de controle racial, adotando princípios da eugenia, concepção racista que ganhava espaço nesse período (KUHLMANN JÚNIOR, 1998).

Conclui-se que a educação para os filhos dos trabalhadores e as crianças pobres teve nesse período um sentido de compensação. Via-se a criança como aquela que precisava ser assistida e cuidada, pois mudanças ocorriam

59 Os primeiros jardins de infância criados no Brasil foram: o Colégio Menezes Vieira, fundado em 1875 no Rio de Janeiro, e a Escola Americana, de 1877, em São Paulo; e no setor público, o jardim de infância anexo à Escola Normal Caetano de Campos, de 1896, que atendia os filhos da burguesia paulistana (KRAMER, 1987; ROSEMBERG, 1989).

60 Friedrich Froebel (1782-1852) nasceu e viveu na Prússia. Trabalhou juntamente com Pestalozzi (1746-1827) e em 1837 abriu o primeiro jardim de infância (Kindergarden). 
PARTE II - AS POLÍTICAS PÚBLICAS PARA A EDUCAÇÃO INFANTIL...

no âmbito familiar e nas relações sociais. $O$ processo de implantação dessas instituições foi vinculado aos órgãos governamentais de assistência social, e não ao sistema educativo. Seu atendimento era de caráter assistencialista e sua concepção de criança era engendrada pela contradição de luta de classes. Kuhlmann Júnior (1998, p.183) pondera que tal educação "[...] pretendia preparar os atendidos para permanecer no lugar social a que estariam destinados". Por conseguinte, previa-se uma educação assistencialista que mantivesse a condição social da classe, uma educação desigual tal qual o é a sociedade. Afirma o autor:

[...] a história da assistência tem sido também a da produção de uma imagem do pobre como ameaça social a ser controlada. As instituições cumpririam uma função apaziguadora. Interpreta-se a pobreza a partir da generalização de caracterizações parcializadas (KUHLMANN JÚNIOR, 1998, p. 28).

A história da Educação Infantil se mostra contraditória. As propostas foram ambíguas desde sua origem institucional, predominando a concepção educacional assistencialista, preconceituosa em relação à pobreza e descomprometida com a qualidade do atendimento, como afirma Kuhlmann Júnior (1998, p. 202):

[...] $\mathrm{O}$ atendimento educacional da criança pequena passa a ser visto como um favor aos pobres, que se estabelece por meio ao repasse das escassas verbas públicas, às entidades assistenciais na prestação do serviço à população.

Esse dado é alarmante, pois a péssima qualidade acaba se transformando em algo aceito como natural, corriqueiro e mesmo necessário. $\mathrm{O}$ autor alerta: 
Políticas públicas para a educaçäo infantil no brasil (1990-2001)

[...] Com isso, abrem-se portas para os usos político e religioso da instituição: a creche funciona com dinheiro público, mas a entidade, por oferecer o serviço, age como se tivesse o direito de utilizar o equipamento para se autopromover, para dar prestígio a políticos, para a doutrinação teológica e confessional, numa afronta às liberdades fundamentais do cidadão, definidas por nossa Constituição (KUHLMANN JÚNIOR, 1998, p. 202).

Enfatiza-se que foi predominantemente assistencialista o atendimento à classe majoritária, mas os filhos da elite eram atendidos de outras formas, em instituições privadas.

Kramer (1987), ao apresentar o histórico do atendimento à criança brasileira, explica que a educação pré-escolar destinada às elites, como os jardins de infância, de orientação froebeliana, teve como principais expoentes, no Rio de Janeiro, o Colégio Menezes Vieira, fundado em 1875, e em São Paulo, e a Escola Americana, de 1877. No setor público havia o jardim de infância anexo à Escola Normal Caetano de Campos, de 1896, que, mesmo sendo oficial, atendia os filhos da burguesia paulistana.

Nesse contexto, duas tendências caracterizavam o atendimento à criança em idade pré-escolar:

[...] o governo proclama(va) a sua importância e mostra(va) a impossibilidade de resolvê-lo dada as dificuldades financeiras em que se encontra(va), enquanto imprimia uma tendência assistencialista e paternalista à proteção da infância brasileira, em que o atendimento não se constituía em direito, mas em favor. Ambas as tendências ajudam a esconder que o problema da criança se origina na divisão da sociedade em classes sociais (KRAMER, 1987, p. 64). 
PARTE II - AS POLÍTICAS PÚBLICAS PARA A EDUCAÇÃO INFANTIL...

Kramer (1987) comenta que os anos 1930 foram marcados por modificações políticas econômicas e sociais em estreita relação com o cenário internacional, o que, numa compreensão geral, evidenciou-se na configuração de um atendimento à infância caracterizado pela relação entre educação e saúde. A partir deste contexto ampliou-se o atendimento, mas o enfoque ainda permaneceu voltado para uma educação assistencialista e compensatória.

Em se tratando das políticas públicas para a Educação Infantil no final da década de 1970 e início da de 1980, observase que essas políticas adquiriram força a partir do movimento de democratização do país na década de 1980, o qual pôs em discussão vários setores sociais. Neste contexto, a Educação Infantil, até então distante de um caráter definido e educativo, desprovida de regulamentações e políticas específicas, passou a ser foco de discussão no âmbito da reforma educacional do país.

Kuhlmann Júnior (1998, p.197) sobre esse contexto refere que:

[...] A caracterização das instituições de educação infantil como parte dos deveres do Estado com a educação, expressa já na Constituição de 1988, tratase de uma formulação almejada por aqueles que, a partir do final da década de 70, lutaram [...] pela implantação de creches e pré-escolas que respeitam os direitos das crianças e das famílias.

Esse momento, em decorrência da luta contra o regime militar, foi um período de grande generalização dos movimentos sociais. As creches foram um resultado concreto dessas lutas. A legislação brasileira, ao ampliar o conceito de Educação Básica, a partir da Constituição Federal de 1988, coloca a Educação 
Políticas públicas para a educaçäo infantil no Brasil (1990-2001)

Infantil junto com o Ensino Fundamental e Médio, passando ela a ser considerada a primeira etapa da Educação Básica.

Kuhlmann Júnior (1998), ao criticar a concepção assistencialista de educação, concebe que o reconhecimento das creches e pré-escolas como parte do sistema educacional na Constituição de 1988 e na Lei de Diretrizes e Bases N. 9 9.394/96 pode ser tido como a superação de um obstáculo:

[...] Se a creche passa a fazer parte do sistema educacional do país, ela deixa de ser apresentada como alternativa para pobres incapazes, para ser posta como complementar à ação da família, tornando-se uma instituição legítima e não um simples paliativo (KUHLMANN JÚNIOR, 1998, p. 204).

Acrescenta o autor que as instituições não se tornam educacionais por esse motivo, mas elas sempre foram educacionais e assim continuarão, haja vista que a passagem para o sistema educacional não representou a superação dos preconceitos sociais que envolviam a Educação Infantil (KUHLMANN JÚNIOR, 1998).

O contexto que leva à elaboração da legislação a partir de políticas traçadas e do que estas definem sobre a infância e sua educação, expressa as contradições da sociedade que nelas são refletidas. Oliveira (2000, p.15) define que a década de 1990 pode ser considerada como um período fecundo em termos de formulação de propostas no campo educacional, pois nessa década ocorreram discussões acerca de um padrão de qualidade emergente no contexto de reestruturação produtiva e de globalização da economia. Argumenta que essas

\footnotetext{
[...] discussões explicitam a necessidade de se repensarem e de se proporem alternativas para
} 
PARTE II - AS POLÍTICAS PÚBLICAS PARA A EDUCAÇÃO INFANTIL...

os problemas estruturais da educação brasileira, passando necessariamente pela reforma dos sistemas públicos de ensino.

Esse contexto de reformas político-educacionais demandou uma multiplicidade de mudanças no âmbito educacional, as quais, conforme a autora, justificaram-se

[...] pela necessidade de se encontrarem respostas e soluções exequíveis para os problemas de insuficiência no atendimento, por parte do poder público, da universalização do ensino básico, e consequentemente, das novas demandas econômicas no contexto da globalização capitalista (OLIVEIRA, 2000, p. 18).

A atual legislação brasileira, ao ampliar, a partir da Constituição Federal de 1988, o conceito de Educação Básica, estabeleceu essa etapa como um processo que engloba a Educação Infantil, o Ensino Fundamental e o Ensino Médio; portanto essa ampliação deveria ser concebida como um compromisso maior do Estado com a educação em geral, representado por um mais amplo acesso das populações à escolarização formal. Os entraves à concretização dessa proposta são muitos. Como ressalta Oliveira (2000, p.19),

Ocorre que a realidade é desigual. Essa desigualdade não é apenas geográfica, mas sobretudo social. A educação como forma de mobilidade social - ideia amplamente explorada no passado - e a atual educação para a empregabilidade do presente mitificam a realidade, como se o problema fosse apenas conjuntural, bastando, para solucionálo, intervenções pontuais, como mecanismos de melhor distribuição de renda. Tal interpretação relega o aspecto político a um problema meramente distributivo. 
Políticas públicas para a educaçäo infantil no Brasil (1990-2001)

A compreensão das políticas para a Educação Infantil no Brasil, de seus postulados, diretrizes e programas diante do contexto mundializado, vai além da realidade meramente brasileira. As diversas e contínuas mudanças na economia e na cultura, que aqui provocam transformações sociais, ocasionam também modificações universais no funcionamento das famílias e na educação das crianças em todas as camadas sociais. Para Rossetti-Ferreira, Ramon e Silva (2002, p. 68),

\footnotetext{
O crescente processo de industrialização, as guerras e conflitos que provocam migrações internas e externas, mudanças na concepção sobre a importância e influência dos primeiros anos de vida para o desenvolvimento posterior e a conquista de direitos da mulher e da criança [...] intensas mudanças na estrutura familiar e no papel de cada um de seus membros têm ocorrido por conta da mobilização e crescimento da participação da mulher no mercado de trabalho.
}

Todos esses fatores, de amplitude macroeconômica, contribuem para o aumento da demanda pela educação e cuidado das crianças na Educação Infantil. As várias políticas propostas são respostas desse processo social. As autoras, ao se referirem a essa questão, afirmam que "[...] esse processo temse configurado de formas diversas nos países desenvolvidos e naqueles em desenvolvimento, principalmente no que se refere às camadas mais pobres da população" (ROSSETTI-FERREIRA; RAMON; SILVA, 2002, p. 70). Essa afirmação inaugura uma visualização do objeto estudado diante do contexto de mundializado, pois se sabe que a focalização na pobreza é uma estratégia para a permanência da dominação econômica dos países centrais sobre os periféricos.

A análise das políticas públicas para a Educação Infantil no contexto mundializado permite compreender as mudanças 
estruturais que influenciaram as políticas públicas no âmbito educacional a partir da década de 1990. Essa compreensão se tornou possível mediante um percurso teórico-metodológico que direcionou a escolha de fontes documentais. Fez-se necessário realizar reflexões a partir de dois percursos: 1)- a compreensão da influência das agências internacionais e dos princípios norteadores de suas propostas, orientações e programas para os países em desenvolvimento, entre eles o Brasil; 2)- a análise das políticas governamentais e dos dispositivos legais que regulamentam a Educação Infantil previstos na Constituição Federal de 1988, no Estatuto da Criança e do Adolescente (Lei n. ${ }^{\circ}$ 8.069/90), na Lei de Diretrizes e Bases da Educação Nacional (LDB) n. ${ }^{\circ}$ 9.394/96, no Plano Nacional de Educação - Lei no 10.172/2011, no Referencial Curricular Nacional para a Educação Infantil - RCNEI e nas Diretrizes Nacionais para a Educação Infantil - DCNEI.

Sobre o procedimento de análise das políticas educacionais, Vieira (2001) afirma que para investigá-las é necessário um esforço de síntese, ordenação e análise pautado em um debate de maior amplitude e complexidade, não deve se tratar de identificar uma continuidade entre agendas governamentais de política, mas sim, de examinar a Educação Infantil no momento histórico em foco, procedimento imprescindível para constatar divergências, controvérsias e contradições.

\subsection{POLÍTICAS PARA A EDUCAÇÃO INFANTIL E AS AGÊNCIAS INTERNACIONAIS}

As políticas educacionais recentes do Brasil e de outros diversos países estão marcadas por discursos específicos ao 
atendimento da primeira infância como prioridade para o desenvolvimento sustentável dos países. Esse tema tornou-se recorrente a partir de 1990 e tem com foco a educação e o cuidado infantil. Em 1990, na Conferência Mundial de Educação para Todos, realizada em Jomtien, na Tailândia, 183 países (entre eles o Brasil) assumiram o compromisso de, até 2000, satisfazer as necessidades básicas de aprendizagem das crianças, jovens e adultos, erradicar o analfabetismo e universalizar o acesso à escola na infância. Na Declaração de Jomtien reconheceu-se que a aprendizagem inicia-se com o nascimento:

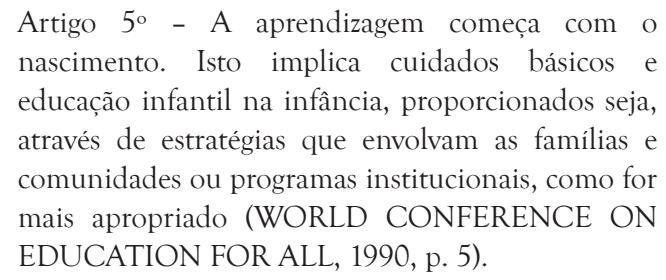

Em abril de 2000 realizou-se o Fórum Mundial de Educação para Todos em Dakar/Senegal, com o intuito de avaliar os progressos alcançados na década e estabelecer novas metas. O Marco de Ação Dakar fixou seis metas, a primeira das quais consiste em "Expandir e melhorar o cuidado e educação da criança pequena, especialmente para as crianças pequenas mais vulneráveis e em maior desvantagem" (UNESCO, 2000, p. 2).

Até o presente momento, no tocante às novas metas definidas em Dakar, o Brasil já dispõe de uma legislação no campo dos direitos e atendimento às crianças de zero a cinco anos que alguns consideram avançada. Em 2001 foi sancionada a Lei n. ${ }^{\circ}$ 10.172, que aprovou o Plano Nacional de Educação e estabeleceu metas para a Educação Infantil tendo como base as recomendações mundiais. 
PARTE II - AS POLÍTICAS PÚBLICAS PARA A EDUCAÇÃO INFANTIL...

Observa-se que em documentos dos organismos internacionais divulgados pela União Europeia, Estados Unidos e América Latina essa marca que prioriza a educação e o cuidado infantil na primeira infância é recomendada, mas depende da concordância dos Estados Nacionais signatários.

Para evidenciar as recomendações políticas das agências internacionais, escolheu-se para este estudo apenas um documento de cada organismo internacional que tratasse sobre o atendimento à infância de zero a seis anos. Foram priorizados documentos assinados no período entre 1990 e 2005, ou seja, nos últimos quinze anos, com o intuito de retratar as políticas recomendadas no contexto atual da Educação Infantil.

O objetivo desse procedimento é analisar, nas fontes examinadas, as principais orientações políticas das agências intergovernamentais com as quais o MEC mantém relacionamento mais estreito, a saber:

1) UNESCO. Marco de Ação Dakar (2000);

2) UNESCO. Os serviços para a criança de zero a seis anos no Brasil (2003);

3) BANCO MUNDIAL. Relatório sobre o Desenvolvimento Mundial (1990);

4) BANCO MUNDIAL. Relatório sobre o Desenvolvimento Mundial (1995b);

5) BANCO MUNDIAL. Relatório sobre o Desenvolvimento Mundial (1996);

6) BID. Romper el ciclo de la pobreza: investir na infância. (1999);

7) CEPAL. Acerca de la CEPAL (2005).

A escolha desses organismos deveu-se à sua forte presença na formulação das políticas educacionais no Brasil a partir da década de 1990. Em certas situações essas agências são responsáveis pela determinação de políticas educacionais 
integrais, as quais ganham hegemonia junto ao aparelho do Estado.

O foco dessa compreensão está em perceber que as políticas recomendadas pelos organismos internacionais aos países do Terceiro Mundo - no caso, o Brasil - estão coligadas entre si e inseridas em uma teia de relações com o contexto mundializado do capital. Os países-membros direcionam os rumos da Educação Infantil com políticas e ações demandadas mundialmente.

Uma das causas desse direcionamento está na subordinação dos países periféricos às condições dos acordos dos empréstimos e ao redirecionamento apropriado de suas políticas macroeconômicas de acordo com os interesses comercais dos países credores (CHOSSUDOVSKY, 1999). O capital internacional se alimenta do retorno político-econômico que essas regulações internacionais lhe proporcionam.

Em relação ao Brasil, um exemplo para compreender melhor essa questão é o interesse das nações centrais de que o país continuasse na condição de dependência por sua dívida externa. Chossudovsky (1999, p.171) explica que:

\footnotetext{
Os credores internacionais do Brasil queriam assegurar de que o país permaneceria endividado por muito tempo e de que a economia nacional e o Estado seriam reestruturados em benefícios deles (credores) por meio da contínua pilhagem dos recursos naturais e do meio ambiente, da consolidação da economia de exportação baseada na mão de obra barata e da aquisição das empresas estatais mais lucrativas pelo capital estrangeiro.
}

Desta maneira, uma das medidas é a privatização. Os bens do Estado são privatizados em troca da dívida, e os custos do 
PARTE II - AS POLÍTICAS PÚBLICAS PARA A EDUCAÇÃO INFANTIL..

trabalho são comprimidos em consequência da desindexação dos salários e das demissões engendradas pelas reformas macroeconômicas. A pobreza não foi apenas "o resultado" das reformas, ela foi também uma "condição explícita" do acordo com o FMI (CHOSSUDOVSKY, 1999).

Essa medida de expor as estratégias políticas das agências internacionais para a Educação Infantil possibilitará o destaque de algumas categorias discursivas ${ }^{61}$ que estiveram presentes nas orientações dessas agências para a formulação das políticas educacionais para o Brasil, as quais influenciaram a legislação e as ações do Estado Brasileiro referentes à questão. Algumas dessas categorias também foram específicas à Educação Infantil e serão utilizadas como guia para a análise dos textos veiculados nas revistas de ensino "Nova Escola" e "Criança". A partir da compreensão coligida dos documentos, buscou-se identificar essas categorias e defini-las como termos que representam indícios da compreensão acerca da realidade social contemporânea.

\subsubsection{Educação Infantil e a Organização das Nações Unidas para a Educação, a Ciência e a Cultura (UNESCO)}

A Organização das Nações Unidas para a Educação, a Ciência e a Cultura (UNESCO) se caracteriza como uma agência das Nações Unidas especializada em educação. Foi criada em Londres, em 1945, ao término da Segunda Guerra Mundial, e hoje está sediada em Paris.

61 A fim de visualizar essas categorias no texto, optou-se por destacá-las em negrito, como segue. 
O principal enfoque da Unesco está no aprimoramento da educação mundial por meio de acompanhamento técnico, do estabelecimento de parâmetros e normas e de projetos e redes de comunicação. A agência se define como um catalisador da proposta e disseminação de soluções inovadoras para os desafios encontrados. O Ministério da Educação e Cultura (MEC), ressaltando a importância de sua parceria com a Unesco, afirma:

No âmbito das Nações Unidas, a Unesco tem a responsabilidade de fortalecer, na mente dos homens, os pilares da paz, mediante o desenvolvimento da cooperação internacional em suas esferas de competência e, dentre outras, a da educação, considerada primordial nas perspectivas de desenvolvimento humano (BRASIL, 2005, p. 2).

A organização mantém contato com ministérios de Educação e outros parceiros em 188 países. O Brasil é membro desde 4 de novembro de 1946, pertencendo ao grupo E-962, considerado o grupo dos países mais populosos do mundo. Para esses países, a Unesco (2005, p. 12) divulga que:

[...] promove ações prioritárias de desenvolvimento no setor de Educação. A principal diretriz da UNESCO é a Educação para Todos, onde são desenvolvidas ações direcionadas ao fortalecimento da capacidade nacional, acompanhamento técnico, apoio à implementação de políticas nacionais de educação através de diversos projetos, aprimoramento e democratização da educação em todos os seus níveis e modalidades.

62 Refere-se aos nove países em desenvolvimento com o maior número de população: Bangladesh, Brasil, China, Egito, Índia, Indonésia, México, Nigéria e Paquistão. Esses países, juntos, representam mais da metade da população do mundo, incluindo $71 \%$ do total global de adultos analfabetos e mais da metade das crianças que se encontram fora da escola (UNESCO, 2005) 
PARTE II - AS POLÍTICAS PÚBLICAS PARA A EDUCAÇÃO INFANTIL...

Ao refletir sobre as orientações da Unesco para a Educação Infantil, cumpre salientar que o discurso dessa agência é que a educação da criança de zero a seis anos é um direito constitucional, um compromisso assumido pelo Brasil no Marco de Ação Dakar ${ }^{63}$ e no Plano Nacional de Educação (PNE).

Esse direcionamento comprova a atitude da agência de estimular os países a cumprirem as diretrizes políticas mundiais. A educação tornou-se pauta de discussão nas cúpulas mundiais. Os países se reúnem para discutir a situação da educação no mundo.

A Unesco se diz uma agência disposta a efetivar o direito a uma educação de qualidade para as crianças desde seus primeiros anos de vida. Sua atuação tem como objetivo concretizar as metas estabelecidas pelo PNE e incentivar os estados e municípios a elaborarem seus planos locais de educação contemplando neles a Educação Infantil.

São várias as ações que a Unesco visa desenvolver na área da Educação Infantil. No Brasil, ressaltam-se as seguintes ${ }^{64}$ :

63 Os participantes da Cúpula Mundial de Educação reuniram-se em Dakar, Senegal, em 26 a 28 de abril de 2000, e registraram o Marco da Ação Dakar que representa o compromisso coletivo de alcançar os objetivos e metas de Educação para Todos (EPT) para cada cidadão e cada sociedade. Esse marco determina que "[...] os governos têm a obrigação de assegurar que os objetivos e metas de EPT sejam alcançados e mantidos. Essa responsabilidade será atingida de forma eficaz através de amplas parcerias no âmbito de cada país, apoiada pela cooperação com agências e instituições regionais e internacionais" (UNESCO, 2000, p.1). Na ocasião, os governos adiaram o compromisso assumido em Jomtiem para mais 15 anos. Foram definidas mais 6 metas e propostas 12 grandes estratégias para o alcance de uma "educação para todos" até o ano de 2015.

64 As informações estão disponíveis em: <http:www.unesco.org.br/areas/educacão/Educacao/educacao>. Acesso em: 20 nov. 2005. 
Políticas públicas para a educaçäo infantil no Brasil (1990-2001)

\section{Ações da Unesco para a Educação Infantil no Brasil}

Adoção de uma linha editorial na área da educação infantil, incluindo a tradução de Notas sobre Políticas ("Policy Briefs") de vários países, que contêm lições sobre suas políticas para a infância, produzidas pela Sede da UNESCO e já traduzidas para outras línguas;

- Parceria com a Fundação Orsa como o objetivo de contribuir para a disseminação de informação, formação de profissionais e aprimoramento da política de educação infantil no Brasil. Salienta-se a publicação da Revista Coordinators Notebook - A infância em debate: perspectivas contemporâneas, realizada em parceria da Fundação Orsa, Unesco e o Consultative on Early Childhood care and Development;

- Realização do estudo "Os serviços para a criança de 0 a 6 anos no Brasil", uma iniciativa da Sede da UNESCO para levantamento da situação da Educação Infantil em vários países. O estudo foi publicado em português e inglês, visando a uma disseminação para outros países interessados em conhecer a realidade brasileira;

- Adoção de uma linha editorial na área da educação infantil, incluindo a tradução de Notas sobre Políticas ("Policy Briefs") de vários países, que contêm lições sobre suas políticas para a infância, produzidas pela Sede da UNESCO e já traduzidas para outras línguas;

Parceria com a Fundação Orsa como o objetivo de contribuir para a disseminação de informação, formação de profissionais e aprimoramento da política de educação infantil no Brasil. Salienta-se a publicação da Revista Coordinators Notebook - A infância em debate: perspectivas contemporâneas, realizada em parceria da Fundação Orsa, Unesco e o Consultative on Early Childhood care and Development;

- Realização do estudo "Os serviços para a criança de 0 a 6 anos no Brasil", uma iniciativa da Sede da UNESCO para levantamento da situação da Educação Infantil em vários países. O estudo foi publicado em português e inglês, visando a uma disseminação para outros países interessados em conhecer a realidade brasileira;

- Pesquisa sobre indicadores da primeira infância, promovido pelo Escritório regional da UNESCO para a América Latina e o Caribe (OREALC), visando a aperfeiçoar o monitoramento global de Educação para Todos. O Brasil foi incluído no projeto pela sua extensão territorial e complexidade, visto 
que a oferta da educação infantil é cada vez mais descentralizada em nível de milhares de municípios;

- Projeto "Revisão das Políticas e Serviços de Educação infantil", estudo promovido pela Unesco - Sede e a Organização para Cooperação e desenvolvimento Econômico (OCDE), envolvendo quatro países-membros: Brasil, Indonésia, Cazaquistão e Quênia. A iniciativa visa a oferecer a esses países uma oportunidade de revisar criticamente suas políticas e serviços para a primeira infância e identificar opções e estratégias para melhorá-los. Além disso, no nível global, pretende disseminar informações comparativas sobre as políticas, planejamento e implementação de educação infantil. 0 projeto é desenvolvido em parceria com o ministério da Educação por meio da Secretaria de Educação infantil e Fundamental e do Instituto nacional de Estudos e pesquisas Educacionais Anísio Teixeira;

- Realização de Seminário para promover debates e subsidiar a educação infantil no Brasil, como simpósio de educação Infantil: construindo o presente, em comemoração à semana de Educação para Todos de 2002 e o Seminário nacional sobre o Financiamento da Educação infantil, em setembro de 2003;

- Intercâmbio Internacional, promovendo a troca de experiências;

- Programa Fundo do Milênio para a Primeira Infância: este programa firmado em 2003 tem como parceiros a Unesco no Brasil, o Banco Mundial e a Fundação Maurício Sirotsky Sobrinho. Tem como objetivo a qualificação do atendimento em creches e pré-escolas - preferencialmente da rede privada sem fins lucrativos, isto é, de instituições comunitárias, filantrópicas e confessionais que atende crianças em situação de vulnerabilidade social. [...] Empresas socialmente responsáveis têm participado no cofinanciamento do Programa, compartilhando a visão de que os primeiros anos de vida valem para sempre e que a educação de qualidade, desde a mais tenra infância, é fundamental para a construção de um Brasil mais desenvolvido, mais humano e socialmente mais justo (UNESCO, 2005, p.1415).

O foco dessas ações é refletir acerca de algumas considerações do Marco de Ação Dakar. Com o estabelecimento do compromisso coletivo de alcançar os 
objetivos e metas da EPT, os governos dos países, por meio de parcerias, cooperação com agências e instituições regionais e internacionais, visam reafirmar a concepção de uma educação para todos, de direito e transformadora. Fazem-se presentes nas recomendações traçadas em Dakar as delimitações políticas educacionais do relatório da Unesco denominado Relatório Jacques Delors - Educação: um tesouro a descobrir (1998), no qual este recomenda que à educação cabe a descoberta de talentos e potencialidades tendo como eixo articulador as necessidades básicas de aprendizagem. Nesse documento são definidos quatro pilares: Aprender a conhecer; Aprender a fazer; Aprender a viver juntos; e Aprender a ser (DELORS, 1998, p. 101-102). No texto adotado pela Cúpula Mundial de Educação em Dakar, encontramos o que está expresso na definição abaixo.

\section{Marco de Ação Dakar \\ Concepção de Educação para Todos}

[...] toda criança, jovem e adulto têm o direito humano de se beneficiar de uma educação que satisfaça suas necessidades básicas de aprendizagem, no melhor e mais pleno sentido do termo, e que inclua aprender a aprender, a fazer, a conviver e a ser. É uma educação que se destina a captar os talentos e potencial de cada pessoa e desenvolver a personalidade dos educandos para que possam melhorar suas vidas e transformar suas sociedades (UNESCO, 2000, p. 1)

O conceito de educação expresso para os países é exposto nesse documento como um direito humano que levará à transformação das sociedades. Desse modo, na visão da Unesco, a responsabilidade por mudanças e transformações na sociedade recai sobre a educação. 


\section{Marco de Ação Dakar \\ Educação para o trabalho e diminuição das desigualdades}

[...] jovens e adultos não têm as habilidades e conhecimentos necessários para um emprego proveitoso e para participarem plenamente em suas sociedades. Sem um progresso acelerado na direção de uma educação para todos, as metas nacionais e internacionais acordadas para a redução da pobreza não serão alcançadas e serão ampliadas as desigualdades entre as nações e dentro das sociedades (UNESCO, 2000, p. 1).

A educação, tida pela Unesco como um direito humano fundamental, é considerada a chave para um desenvolvimento sustentável e para assegurar a paz e a estabilidade dentro e entre os países,, portanto, como um meio indispensável para alcançar a participação efetiva nas sociedades e economias do século XXI.

Os objetivos firmados com os quais a Unesco orienta os países a comprometer-se são:

\section{Marco de Ação Dakar Objetivos traçados para os países}

expandir e melhorar o cuidado e a educação da criança pequena, especialmente para as crianças mais vulneráveis e em maior desvantagem;

assegurar que todas as crianças, com ênfase especial nas meninas e crianças em circunstâncias difíceis, tenham acesso à educação primária, obrigatória, gratuita e de boa qualidade até o ano 2015;

assegurar que as necessidades de aprendizagem de todos os jovens e adultos sejam atendidas pelo acesso equitativo à aprendizagem apropriada, à habilidade para a vida e à programas de formação para a cidadania;

alcançar uma melhoria de $50 \%$ nos níveis de alfabetização de adultos até 2015, especialmente para as mulheres, e acesso equitativo à Educação Básica e continuada para todos os adultos; 
eliminar disparidades de gênero na educação primária e secundária até 2005 e alcançar a igualdade de gênero na educação até 2015, com enfoque na garantia ao acesso e o desempenho pleno e equitativo de meninas na Educação Básica de boa qualidade;

melhorar todos os aspectos da qualidade da educação e assegurar excelência para todos, de forma a garantir a todos resultados reconhecidos e mensuráveis, especialmente na alfabetização, matemática e habilidades essenciais à vida (UNESCO, 2000, p. 2).

O primeiro sos objetivos apresentados se refere à Educação Infantil. Percebe-se que nele está presente o discurso da equidade, uma vez que prioriza as crianças mais vulneráveis e em maior desvantagem, caracterizando-se pela focalização na pobreza. Nos demais objetivos evidencia-se a focalização de gênero e a ênfase em uma aprendizagem emergencial básica como essencial para a vida - por conseguinte, evidencia-se uma focalização no ensino básico, mais especificamente o nível fundamental.

Um estudo realizado pela Unesco intitulado "Os serviços para a criança de 0 a 6 anos no Brasil" demonstra a articulação de políticas a partir da década de 1990 para essa área. O objetivo do estudo esta descrito abaixo.

Os serviços para a criança de 0 a 6 anos no Brasil Articulação de políticas

[...] contribuir para a superação dos desafios que se impõem ao cumprimento do compromisso assumido, em Dakar, de dar acesso às crianças pequenas a experiências educacionais de qualidade (UNESCO, 2003, p. 8).

Destaca-se a seguir o panorama da Educação Infantil no Brasil segundo estudo realizado pela Unesco, bem como as recomendações desse estudo. $\mathrm{O}$ procedimento nele utilizado 
PARTE II - AS POLÍTICAS PÚBLICAS PARA A EDUCAÇÃO INFANTIL...

evidencia os serviços e os programas, os atendimentos e a articulação das políticas educacionais para as crianças de zero a 6 anos.

Quanto aos serviços destinados à primeira infância, a tabela 1 mostra seis tipos de atendimento: creche, pré-escola, apoio à criança e ao adolescente em abrigos, apoio à pessoa portadora de deficiência, atenção primária à saúde e assistência hospitalar, sendo que o atendimento em creches das crianças de zero a três anos inclui instituições públicas e privadas e representa 9,15\% dos atendimentos até 1999 (Pesquisa Nacional por Amostra de Domicílio - PNAD), e nas pré-escolas o atendimento às crianças de quatro a seis anos representa 52\% do total.

Tabela 1: Serviços para crianças de zero a seis anos

\begin{tabular}{|c|c|c|c|c|}
\hline $\begin{array}{l}\text { Nome } \\
\text { designação do } \\
\text { serviço }\end{array}$ & $\begin{array}{l}\text { Estruturas } \\
\text { (escola, } \\
\text { centro, } \\
\text { domicílio) }\end{array}$ & Faixa etária & $\begin{array}{c}\text { Horário de } \\
\text { funcionamento }\end{array}$ & $\begin{array}{l}\text { Ministério } \\
\text { responsável }\end{array}$ \\
\hline Creche & Escola/creche & 0 a 3 anos & $\begin{array}{l}\text { Tempo integral ou } \\
\text { tempo parcial }\end{array}$ & Educação \\
\hline Pré-escola & Escola/creche & 4 a 6 anos & $\begin{array}{l}\text { Tempo integral ou } \\
\text { tempo parcial }\end{array}$ & Educação \\
\hline $\begin{array}{l}\text { Apoio à criança } \\
\text { e ao adolescente } \\
\text { Abrigo }\end{array}$ & $\begin{array}{l}\text { Espaços } \\
\text { coletivos } \\
\text { (casas) de } \\
\text { moradias } \\
\text { provisórias, } \\
\text { com guardião } \\
\text { responsável }\end{array}$ & $\begin{array}{l}0 \text { a } 18 \text { anos } \\
\text { (excepcionalmente } \\
\text { até } 21 \text { anos) }\end{array}$ & $\begin{array}{l}\text { Ininterrupto (todos } \\
\text { os dias } 24 \text { horas } \\
\text { por dia) }\end{array}$ & $\begin{array}{l}\text { Previdência } \\
\text { Assistência } \\
\text { Social }\end{array}$ \\
\hline $\begin{array}{l}\text { Apoio à Pessoa } \\
\text { Portadora de } \\
\text { Deficiência }\end{array}$ & $\begin{array}{l}\text { Várias: } \\
\text { comunidade, } \\
\text { domicílio, } \\
\text { centro-dia, } \\
\text { abrigo, clínicas }\end{array}$ & $\begin{array}{l}\text { Crianças, } \\
\text { adolescentes, } \\
\text { adultos e idosos }\end{array}$ & $\begin{array}{l}\text { Variados, por } \\
\text { modalidade de } \\
\text { atendimento. São } \\
11 \text { modalidades }\end{array}$ & $\begin{array}{l}\text { Previdência } \\
\text { Assistência } \\
\text { Social }\end{array}$ \\
\hline
\end{tabular}


Políticas públicas para a Educaçäo Infantil no Brasil (1990-2001)

\begin{tabular}{l|l|l|l|l} 
l... Continuação & $\begin{array}{l}\text { Unidades } \\
\text { Básicas de } \\
\text { Atenção Primária } \\
\text { à Saúde } \\
\text { Saúde; } \\
\text { Domicílio } \\
\text { (Saúde Família) }\end{array}$ & $\begin{array}{l}\text { Crianças, } \\
\text { adolescentes, } \\
\text { adultos e idosos }\end{array}$ & $\begin{array}{l}\text { Durante o dia } \\
\text { cinco dias por } \\
\text { semana }\end{array}$ & Saúde \\
\hline $\begin{array}{l}\text { Assistência } \\
\text { Hospitalar }\end{array}$ & Hospitais & $\begin{array}{l}\text { Crianças, } \\
\text { adolescentes, } \\
\text { adultos e idosos }\end{array}$ & $\begin{array}{l}\text { Ininterrupto (todos } \\
\text { os dias 24 horas } \\
\text { por dia) }\end{array}$ & Saúde \\
\hline
\end{tabular}

Fonte: Unesco (2003, p.13).

A Unesco apresenta três tipos de programas destinados à primeira infância:

A Benefícios de Prestação Continuada (BPC) - Ministério da Assistência Social;

B Bolsa-Alimentação - Ministério da Saúde;

C Alimentação Escolar - Ministério da Educação.

Quanto ao atendimento em creches e pré-escolas, os dados numéricos do censo demográfico de 2000 (apud UNESCO, 2003) apontam que a população total do Brasil era de 169.799.170 habitantes, dos quais 13.020.216 eram crianças de zero a três anos, e 10.121.197, crianças de quatro a seis anos. Somando-se esses dois totais, a estimativa era de que no Brasil havia 23.141.413 (13,6\%) crianças de zero a seis anos. As crianças de zero a três anos representam 7,6\% do total de habitantes e as de quatro a seis representam $6,0 \%$, distribuídos regionalmente conforme a tabela 2 .

Tabela 2: Brasil - População residente e população de zero a seis anos, pelas grandes regiões.

\begin{tabular}{l|c|c|c}
\hline \multicolumn{1}{c|}{ Região } & $\begin{array}{c}\text { População } \\
\text { (a) }\end{array}$ & $\begin{array}{c}\text { População de 0 a 6 } \\
\text { anos (b) }\end{array}$ & $\begin{array}{c}\text { Porcentagem (b/a) } \\
\mathbf{x 1 0 0}\end{array}$ \\
\hline Norte & 12.900 .704 & 2.306 .485 & $17,9 \%$ \\
\hline \multicolumn{3}{|r}{}
\end{tabular}


PARTE II - AS POLÍTICAS PÚBLICAS PARA A EDUCAÇÃO INFANTIL...

\begin{tabular}{l|l|l|l} 
/... Continuação & \\
\hline Nordeste & 47.741 .711 & 7.156 .174 & $15,0 \%$ \\
Sudeste & 72.412 .411 & 8.899 .076 & $12,3 \%$ \\
Sul & 25.107 .616 & 3.160 .302 & $12,6 \%$ \\
Centro- & 11.636 .728 & 1.619 .376 & $13,9 \%$ \\
Oeste & $\mathbf{1 6 9 . 7 9 9 . 1 7 0}$ & $\mathbf{2 2 3 . 1 4 1 . 4 1 3}$ & $\mathbf{1 3 , 6 \%}$ \\
\hline TOTAL &
\end{tabular}

Fonte: Instituto Brasileiro de Geografia e Estatística - Censo Demográfico (2000 apud UNESCO, 2003, p.19).

Quanto à articulação das políticas para a criança de zero a seis anos, a Unesco aponta no documento a fragmentação das ações,como mostra o quadro abaixo.

Os serviços para criança de 0 a 6 anos no Brasil. Fragmentação das ações

[...] Vive-se, portanto, no Brasil, um momento de indefinição quanto à política de educação infantil, pois, apesar de reconhecidas como primeira etapa da Educação Básica, as creches e pré-escolas não contam com recursos suficientes no orçamento da educação; a instituição de âmbito federal que possui recursos financeiros para o atendimento continua sendo a da assistência social (UNESCO, 2003, p. 34).

O papel da Unesco na atuação relativa à infância no Brasil ampliou-se desde a década de 1960 e esteve pautado em medidas de assistência com foco na pobreza, de preferência por meio de programas de atendimento à primeira infância (crianças de zero a três anos), tendo o apoio de parceiros do chamado terceiro setor. Pode-se notar esse marco no Programa Fundo do Milênio para a primeira infância e nos estudos desenvolvidos por aquela agência, como a Revisão das Políticas e Serviços de Educação Infantil desenvolvidos no Brasil, Indonésia, Cazaquistão e Quênia. O compromisso com a qualidade e com o desenvolvimento econômico é outro forte pilar das recomendações da Unesco. 
Políticas públicas para a Educaçäo infantil no Brasil (1990-2001)

\subsubsection{Banco Mundial (BM)}

Na primeira parte foram adiantadas algumas discussões a respeito da atuação do Banco Mundial na educação brasileira no contexto de mundialização do capital. Neste item específico, o objetivo é aprofundar as reflexões sobre algumas orientações políticas educacionais do BM em documentos e programas destinados à Educação Infantil.

O Banco Mundial exerce influência na negociação de programas e projetos educacionais orientados e financiados. Com isso, revela um caráter estratégico no processo de reestruturação neoliberal dos países em desenvolvimento, por meio de políticas de ajuste estrutural (SOARES, 2003). Sua intervenção não é imposta aos países, ao contrário, depende do seu consentimento e de sua anuência. Nos países em desenvolvimento, como o Brasil, as articulações entre as políticas educacionais e organizações como o BM ocorrem com ênfase em três temas: 1)- as agências internacionais como instituições sociais; 2)- o campo de estudo sobre desenvolvimento econômico e social; e 3)- o campo dos conhecimentos setoriais, como a educação, a saúde, a ecologia, a população, o trabalho e a segurança. Estes são ainda recortados por temas transversais como a infância, a raça/etnia, a pobreza e os direitos humanos, os quais são também focalizados na elaboração de pautas das políticas setoriais (ROSEMBERG, 2000).

O Banco representa um instrumento auxiliar do governo norte-americano na execução de sua política externa, pois desde a sua criação os Estados Unidos sempre lideraram a gestão do Banco. Segundo Rosemberg (2000, p.16), 
[...] os estatutos do Banco Mundial estabelecem que a influência nas decisões e votações é proporcional à participação no aporte de capital, o que tem assegurado aos EUA a presidência do Banco Mundial desde a sua fundação, e hegemonia absoluta entre as cinco nações líderes na definição de suas políticas e prioridades.

Compõem o Banco Mundial cinco instituições intimamente associadas, cada qual desempenhando uma função, conforme o quadro abaixo:

- Banco Internacional para a Reconstrução e o Desenvolvimento (BIRD): foi fundado em 1944, é o maior financiador de projetos de desenvolvimento para os países em desenvolvimento de renda média e é o principal catalisador de financiamentos para o mesmo fim provenientes de outras fontes. O Bird se capitaliza primordialmente através de capacitação de recursos nos mercados internacionais de capitais;

- Agência Internacional de Desenvolvimento (AID): foi fundada em 1960 e presta assistência aos países pobres através de créditos de financiamento sem juros com prazos de maturação de 35-40 anos. A capitalização da AID se dá através de aportes governamentais;

- Corporação Financeira Internacional (CFI): apoia o setor privado nos países em desenvolvimento através de empréstimos ou financiamento de capital, além de inúmeros serviços de consultoria;

- Agência Multilateral de Garantias de Investimento (AMGI): oferece garantias aos investidores estrangeiros contra riscos não comerciais e auxilia os governos dos países em desenvolvimento atrair investimentos externo;

- Centro Internacional para Conciliação de Divergência nos Investimentos (CICDI): assegura o fluxo de investimentos externos para os países em desenvolvimento através de instrumentos de arbitragem e conciliação.

Quadro 1: As Instituições que compõem o Banco Mundial

Fonte: Banco Mundial (apud ROSEMBERG, 2000, p. 70). 
Políticas públicas para a Educaçäo Infantil no Brasil (1990-2001)

Segundo Leher, Gentili e Fonseca $(2002)^{65}$, a partir da década de 1990 o BM adquiriu certa hegemonia na condução da política educacional dos países periféricos e transformouse efetivamente em uma espécie de "ministério mundial da educação". Esse contexto denota um novo período, chamado pelo autor de recolonização dos países periféricos. O BM avaliava que o período de desenvolvimento tecnológico autônomo dos países periféricos chegara ao fim, não haveria mais desenvolvimento autônomo, e isto requeria desenvolvimento do mercado interno ${ }^{66}$. Os produtos com maior agregação de conhecimento seriam controlados pelos países do Primeiro Mundo. No tocante ao setor educacional dos países periféricos, a ideia era que não teria mais sentido desenvolver conhecimentos para os quais as disciplinas de formação geral são importantes. Percebese esse enfoque nas orientações políticas do BM e de outros organismos internacionais que fornecem cooperação técnica aos países periféricos quando aqueles organizam acentuam a importância apenas da Educação Básica, do conhecimento necessário a "todos".

No Relatório sobre o Desenvolvimento Mundial de 1990, a educação e o trabalho são definidos pelo BM como os principais bens dos pobres, cmo se observa no documento a seguir.

65 Os argumentos de Roberto Leher que estão expostos foram retirados de uma síntese (elaborada por Laerte M. Santos) da sua fala no 4 CONED (Congresso Nacional de Educação) realizado nos dias 23 a 26 de abril de 2002 em mesa redonda sobre "As políticas de financiamento geradas pelos organismos internacionais para a educação na América Latina”. Ver: <http:// www.cefet.br/edu/eso/textoeducacao.html>.

66 Hoje, dos 3 milhões de patentes, somente 1\% são de países periféricos. Das 400 mil patentes estratégicas, $0 \%$ estão nos países periféricos, ou seja, nenhuma (LEHER; GENTILI; FONSECA, 2002, p. 2). 
Relatório sobre o Desenvolvimento Mundial - 1990 Concepção de Educação e Trabalho:

O principal bem dos pobres é o tempo para trabalhar. A educação aumenta a produtividade deste bem. O resultado, no nível individual, é uma renda mais alta, como demonstram muitos estudos. Pesquisas mais recentes apontam também para uma vinculação mais estreita entre educação e crescimento econômico. [...] Como eram na luta contra a pobreza, porém, a instrução faz muito mais do que aumentar a produtividade da mão-de-obra. A mortalidade infantil abaixo dos cinco decai $9 \%$ para cada ano de instrução que a mãe recebeu. Excluindo-se outros fatores, as crianças cujas mães são mais instruídas tendem a ser mais saudáveis (BANCO MUNDIAL, 1990, p. 85).

No Relatório sobre o Desenvolvimento Mundial (1995b e 1996) encontra-se a orientação aos países periféricos de que estes devem reformar a educação, com o argumento de que investir em capital humano resulta em crescimento econômico, visto que "uma mão de obra bem instruída e sadia é essencial para o crescimento econômico” (BANCO MUNDIAL, 1996, p. 136). Observe-se no quadro abaixo o que diz o BM.

Relatório sobre Desenvolvimento Mundial - 1996 Educação mercadológica

Os ingredientes para uma população sadia são praticamente os mesmos em qualquer sistema econômico, mas o conceito de boa educação muda radicalmente com a transição do planejamento para o mercado. É preciso que os reformadores se concentrem no desenvolvimento de um sistema de educação que seja mais sensível à demanda e ensine a população a pensar com independência e adaptar-se às circunstâncias do mercado (BANCO MUNDIAL, 1996, p.145).

Investir em capital humano é uma orientação que o BM estabelece junto às famílias. Em sua visão, esse investimento melhora o padrão de vida familiar, aumenta as oportunidades 
Políticas públicas para a Educaçäo Infantil no Brasil (1990-2001)

e a produtividade, atrai investimentos de capital e pode elevar a renda da família, com afirma o documento abaixo.

Relatório de Desenvolvimento Mundial - 1995

$$
\text { Capital Humano }
$$

[...] para o crescimento e o bem-estar da família, é universalmente reconhecida a importância do investimento em capital humano, especialmente em educação; a consciência desse fato contribuiu para o crescimento sem precedentes da matrícula escolar em todo o mundo nas últimas décadas [...] (BANCO MUNDIAL, 1995b, p. 42).

Fonseca (1998) discorda da ideia de que educar é adaptar o homem ao mercado de trabalho quando explica que, na concepção do BM, a educação deve estar voltada para o mercado dentro da realidade de um mercado segmentado. $\mathrm{O}$ BM avalia que o setor moderno do mercado de trabalho está decrescendo, ao contrário do tradicional (informal, sem proteção trabalhista), que está em crescimento. A maioria ficará no mercado tradicional, e deve ser assim, conforme o Banco. Não há lugar para todos. A educação deve privilegiar o mercado tradicional. A autora menciona, porém, que tais intenções são colocadas nos documentos sigilosos ${ }^{67}$.

Outro aspecto atual que explica as recomendações políticas do $\mathrm{BM}$ aos países periféricos é a de que a política desse banco está vinculada à renegociação da dívida externa. Leher, Gentili

67 Leher, Gentili e Fonseca (2002, p. 4) retratam que "[...] As políticas do BM ficam esclarecidas através de documentos sigilosos que passam pela burocracia governamental dos países periféricos e cuja reprodução é proibida. Há cores para cada tipo de documento. Para o alto escalão da burocracia o documento é de capa branca. Neste nível ele é reelaborado e enviado para os escalões inferiores onde passa a ter outra cor (amarela - yellow cover, cinza, etc.) e mantendo o sigilo. Até chegar ao domínio público. Neste nível não há mais referências ao Banco Mundial. Fica a impressão para os desavisados que se trata de políticas exclusivamente nacionais”. 
PARTE II - AS POLÍTICAS PÚBLICAS PARA A EDUCAÇÃO INFANTIL...

e Fonseca (2002) afirmam que o socorro do FMI só vem com o seu aval. É por conta disto que se consolida o projeto privatista do BM no campo da educação.

O BM, ao colocar que os problemas da educação na América Latina são de rendimento e produtividade, deixa evidente que, no entendimento de seus gestores, a questão educacional tem um caráter técnico. A solução seria o maior rendimento e produtividade; mas como realizar isto se o financiamento às propostas de educação do BM está vinculado à renegociação da dívida externa? Leher, Gentili e Fonseca (2002), ao discutirem esse aspecto, ponderam que atualmente o Brasil utiliza 25\% dos seus gastos para o pagamento dos encargos financeiros da dívida externa. No setor da saúde aplica 6\%, ou seja, menos de um terço do que FHC pagou de juros. Os gastos com as universidades corresponderam a apenas $2 \%$ dos gastos da União, treze vezes menos do que se gastou com os pagamentos dos juros da dívida externa.

O BM não é apenas uma agência educacional, mas principalmente o sujeito de uma nova ordem internacional, marcada pela globalização e pelo neoliberalismo, um interlocutor no mundo globalizado que:

[...] Tem o poder de aglutinar informações sobre a situação econômica e política das nações periféricas. Tem a preocupação de conter o avanço acelerado da pobreza dos países periféricos pois isto traria consequências prejudiciais aos países do primeiro mundo. Isto explica os seus projetos mais caracterizados por preocupação econômica do que educacional (LEHER; GENTILI; FONSECA, 2002, p. 4). 
Para os autores, o financiamento do BM seria um mito. Essa instituição financeira emprestaria muito pouco para a educação propriamente dita. Além disso, tal empréstimo contribuiria para aumentar a dívida externa, uma estratégia política tautológica de ajuste neoliberal que gera dependência econômica dos países prestatários para com os países credores. O desenvolvimento autônomo ficaria, assim, apenas nos discursos das recomendações. A Educação Básica passava a ser valorizada, pois para os países prestatários importavam apenas os conhecimentos básicos.

\subsubsection{Banco Interamericano de Desenvolvimento (BID)}

$\mathrm{O} \mathrm{BID}^{68}$ é uma instituição financeira regional criada em 1959 e sediada em Washington. Divulga que tem os seguintes objetivos: contribuir para o progresso econômico e social da América Latina e do Caribe, por meio da canalização de seu capital próprio, de recursos obtidos no mercado financeiro e de outros fundos, aos países prestatários; completar os investimentos privados; e prover assistência técnica para a preparação, financiamento e execução de projetos e programas de desenvolvimento.

Os países proprietários do BID são ao todo 47, entre países regionais e extrarregionais. O Brasil é membro do BID desde sua criação, e possui $11 \%$ do capital ordinário e do poder de voto do organismo. A Assembleia de Governadores é a autoridade máxima do banco, estando nela representados os países

68 Ver os dados no site <http://www.iadb.org/aboutus/index.cfm?language=Portuguese>. 
PARTE II - AS POLÍTICAS PÚBLICAS PARA A EDUCAÇÃO INFANTIL...

membros, geralmente através de seus ministros da economia ou de finanças, ou por presidentes dos bancos centrais.

Atualmente o banco tem como prioridade os projetos para a redução da pobreza e a promoção da equidade social, modernização do Estado, integração regional e meio ambiente. Além dos recursos do capital ordinário, o BID possui também o Fundo de Operações Especiais (FOE), que oferece empréstimos concessionais aos países de menor desenvolvimento relativo.

No tocante à infância, um discurso que perpassa as orientações políticas do BID é o de que o investimento na infância contribui para minimizar ou eliminar a pobreza dos países em desenvolvimento (BANCO INTERAMERICANO DE DESENVOLVIMENTO, 1999). No documento do BID intitulado "Romper el ciclo de la pobreza: Investir en la infância" (1999) encontram-se alguns aspectos que comprovam essa focalização na pobreza com vistas ao cuidado infantil, pois no discurso político o banco enfatiza que o desenvolvimento deve acontecer através da liberdade: "[...] Este es el razonamiento básico que proporciona la base para considerar el desarrollo como libertad" (BANCO INTERAMERICANO DE DESENVOLVIMENTO, 1999, p. 3) ${ }^{69}$. Assim, o banco propala que o desenvolvimento econômico sustentável é a ampliação da liberdade humana, como se vê no tópico desenvolvido abaixo.

69 Esse é um raciocínio básico que proporciona a base para considerar o desenvolvimento como liberdade (BANCO INTERAMERICANO DE DESENVOLVIMENTO, 1999, p.3).

70 O êxito de uma economia e de uma sociedade não pode separar-se da vida que podem levar os membros da sociedade, porquanto não somente valorizamos o viver bem e de forma satisfatória, mas também apreciamos ter controle sobre nossas próprias vidas. A qualidade da vida tem que ser julgada não somente pela forma em que terminamos vivendo, mas também pelas alternativas substanciais que temos (BANCO INTERAMERICANO DE DESENVOLVIMENTO, 1999, p.1). (a 
Políticas públicas para a Educaçäo Infantil no Brasil (1990-2001)

Romper el ciclo de la pobreza: Investir en la infancia

El êxito de una economia y de una sociedad no puede separarse de las vidas que pueden llevar los miembros de la sociedad. Puesto que no solamente valoramos el vivir bien y en forma satisfactoria, sino que también apreciamos el tener control sobre nuestras propias vidas, la calidad de la vida tiene que ser juzgada no solamente por la forma en que terminamos viviendo, sino también por las alternativas substanciales que tenemos (BANCO INTERAMERICANO DE DESENVOLVIMENTO, 1999, p. 1)..$^{70}$

No que tange à infância, a ênfase maior está no aspecto básico do cuidado. Impera a concepção de que os demais aspectos do desenvolvimento, especificamente o intelectual e mental, seriam consequências do cuidado e assistência adequada na primeira infância. $\mathrm{O}$ documento em questão apresenta orientações políticas com relação ao cuidado, e os países periféricos são alertados a priorizar esse aspecto na primeira infância. $O$ documento salienta cinco aspectos a serem transformados em ações políticas nos países: 1)- redução da taxa de mortalidade infantil; 2)- saúde materno-infantil como prtevenção; 3)- vínculos sociais; 4)- caráter político; e 5)participação de programas.

Quanto ao primeiro aspecto, o BID estabelece que os investimentos do setor público e privado são necessários para a redução da taxa de mortalidade das crianças menores de cinco anos por meio de programas que atendam aos aspectos relacionados à nutrição, imunização e cuidado infantil, como se lê abaixo.

71 Porém na literatura prática sobre o desenvolvimento, o aumento da expectativa de vida e a redução da mortalidade são tomados agora em conta regularmente como parte integral da contabilidade do desenvolvimento entendido em forma ampla. Além disso, podemos pensar medidas agregadas tais como o "índice de desenvolvimento humano", as quais não podem ser senão defeituosas (como haverá de ser qualquer representação de um vetor complexo de êxitos 


\section{Romper el ciclo de la pobreza: Investir en la infancia}

Pero en la literatura práctica sobre el desarrollo, el aumento de la expectativa de vida y la reducción de la mortalidad son tomados ahora en cuenta regularmente, como parte integral de la contabilidad del desarrollo entendido en forma amplia. Aparte de lo que podamos pensar de medidas agregadas tales como el 'índice del desarrollo humano', que no pueden sé sino defectuosas (como habrá de serlo cualquier representación de un vector complejo de logros por medio de un solo número), el tema de vida o muerte está ahora bien establecido en la literatura del desarrollo (BANCO INTERAMERICANO DE DESENVOLVIMENTO, 1999, p.4). ${ }^{71}$

A preocupação com a redução da taxa está imbricada com a concepção de desenvolvimento econômico sustentável, pois estudos econômicos comprovam matematicamente que o índice de desenvolvimento de um país depende da expectativa de vida e morte de sua população.

A saúde materno-infantil como prevenção tem como consequência uma saúde mental na fase adulta e uma vida economicamente produtiva. As orientações sobre o cuidado na fase gestacional (pré-natal) e reprodutiva e nos primeiros dias após o nascimento da criança contidas nesse documento mostram preocupação apenas com o desenvolvimento econômico, mediante a eliminação da pobreza. No texto do tópico abaixo se encontram alguns argumentos que expressam isso: ${ }^{72}$

por meio de um número somente), o tema da vida ou morte está agora bem estabelecido na literatura do desenvolvimento (BANCO INTERAMERICANO DE DESENVOLVIMENTO, 1999, p. 4).

72 Na verdade, o imperativo de romper o ciclo da pobreza pode ser interpretado por alguns como que é principalmente uma ordem de batalha para lutar contra a perpetuação dos baixos ingressos, porém esta interpretação teria o efeito de reduzir em forma significativa o alcance e a relevância do tema desta conferência (BANCO INTERAMERICANO DE DESENVOLVIMENTO, 1999, p. 4). 
Políticas públicas para a educaçäo infantil no brasil (1990-2001)

Romper el ciclo de la pobreza: Investir en la infancia

En verdad, el imperativo de romper el ciclo de la pobreza puede ser interpretado por algunos como que es principalmente una orden de batalla para luchar contra la perpetuación de los bajos ingresos, pero esta interpretación tendría el efecto de reducir en forma significativa el alcance y la relevancia del tema de esta conferencia (BANCO INTERAMERICANO DE DESENVOLVIMENTO, 1999, p. 4)..$^{72}$

A mortalidade infantil é vista como um empobrecimento dos países, e as medidas referentes à saúde, educação pública, garantia de alimentação, segundo o documento do Banco Interamericano de Desenvolvimento (1999), ajudam a pôr fim no empobrecimento e devem ter lugar central em programas como planejamento integrado e atenção à saúde e à mortalidade de crianças menores de cinco anos.

No tocante ao aspecto "Vinculos sociais", o BID mostra as conexões entre o cuidado na infância e a fase adulta do ser humano, ou seja, as consequências do cuidado na infância para a produção de um indivíduo produtivo na idade adulta. É o que deixa claro o texto do tópico abaixo.

73 Os investimentos na infância são importantes por seu próprio direito, devido a que eles abrem o caminho para toda uma vida de saúde melhor, desempenho mental e físico, e produtividade como o que diz Enrique Iglesias, o Presidente do Banco Interamericano de Desenvolvimento, que diz que "os investimentos apropriados podem nos levar longe para minimizar, e ainda prevenir uma série de outros problemas econômicos e sociais, que vão desde a delinquência juvenil até a maternidade adolescente e a violência doméstica e social.” As capacidades de que desfrutam os adultos estão profundamente condicionadas a sua experiência como crianças (BANCO INTERAMERICANO DE DESENVOLVIMENTO, 1999, p. 5). 
Romper el ciclo de la pobreza: Investir en la infancia

Las inversiones para la infancia son importantes por su propio derecho debido a que ellas abren el camino para toda una vida de mejor salud, desempeño mental y físico, y productividad como lo señala Enrique Iglesias, el Presidente del banco Interamericano de Desarrollo, quien añade que "las inversiones apropiadas pueden llevarnos lejos para minimizar, y aun prevenir una serie de otros problemas económicos y sociales, que van desde la delincuencia juvenil hasta la maternidad adolescente y la violencia doméstica y social." Las capacidades de que disfrutan los adultos están profundamente condicionadas a su experiencia como niños (BANCO INTERAMERICANO DE DESENVOLVIMENTO, 1999$, p. 5$)^{73}$.

Destarte, na visão política do organismo, investir na infância é investir economicamente no desenvolvimento do país. O BID tem uma visão dupla, ou seja, a de investir tanto na educação quanto em outros aspectos da infância, como se nota no trecho abaixo.

\section{Romper el ciclo de la pobreza: Investir en la infancia}

[...] pueden mejorar las capacidades futuras en formas muy distintas [..] pueden hacer directamente que las vidas de los adultos sean más ricas y menos problemáticas ya que una niñez segura en la etapa preparatória puede aumentar nuestra habilidad para vivir una buena vida (BANCO INTERAMERICANO DE DESENVOLVIMENTO, 1999, p. 6). ${ }^{74}$

74 [...] podem melhorar as capacidades futuras em formas muito distintas [...] podem fazer diretamente que as vidas dos adultos sejam mais ricas e menos problemáticas, já que uma infância segura na etapa preparatória pode aumentar nossa habilidade para viver uma vida boa (BANCO INTERAMERICANO DE DESENVOLVIMENTO, 1999, p. 6). 
Políticas públicas para a Educaçäo infantil no Brasil (1990-2001)

\section{d) Caráter político}

No tocante ao quarto aspecto (caráter polítuco), na visão política do BID, o efeito direto do investimento na infância é a possibilidade de uma vida melhor, contribuindo para a capacidade dos seres humanos de melhorar a vida e ser mais produtivos. É o que afirma o texto do tópico a seguir.

Romper el ciclo de la pobreza: Investir en la infancia

Las vidas de los adultos son enriquecidas por medio de estos ingresos y recompensas económicas. Dado que eso a su vez influencia las vidas de sus niños y sus futuras vidas adultas, aquí hay un problema de transmisión acerca del cual el banco Interamericano de Desarrollo ha estado muy preocupado recientemente (BANCO INTERAMERICANO DE DESENVOLVIMENTO, 1999, p. 6). ${ }^{75}$

No texto acima o BID apenas comenta o contexto específico de famílias sustentadas por mulheres e aponta que essa é uma preocupação, uma área de investigação futura para concentrar ações nos próximos anos.

Outra consequência do investimento na criança que o BID apresenta é o vínculo social, ou seja, a convivência com o outro, como se vê abaixo.

75 As vidas dos adultos são enriquecidas por meio de salários e recompensas econômicas. Dado que isso, por sua vez, influencia a vida de suas crianças e suas futuras vidas adultas, aqui há um problema de repasse acerca do qual o banco Interamericano de Desenvolvimento tem estado muito preocupado recentemente (BANCO INTERAMERICANO DE DESENVOLVIMENTO, 1999, p. 6). 
Romper el ciclo de la pobreza: Investir en la infancia

[...] Nuestra habilidad para vivir con otros, para participar en actividades sociales, y para evitar desastres sociales, está también profundamente influenciada por las aptitudes que adquirimos como niños. [...] El éxito de una democracia depende de la participación de los ciudadanos y este no es solamente un asunto de "reacción visceral" para vivir como ciudadanos activos y deliberantes. [...] La experiencia y la calidad de la niñez [...] tienen un efecto profundo sobre las capacidades de los adultos para vivir en forma exitosa en la sociedad (BANCO INTERAMERICANO DE DESENVOLVIMENTO, 1999, p. 6-7)..$^{76}$

\section{e) Participação de programas}

No quinto e último item, "Participação de programas", o documento acentua a importância que têm para o cuidado e o desenvolvimento da infância os programas criados com a contribuição da Organização Mundial da Saúde (OMS), especialmente o programa Manejo Integrado de las Enfermedades de la Niñez (MIEN) ${ }^{77}$, como se observa no trecho abaixo.

76 [...] Nossa habilidade para viver com outros, para participar em atividades sociais, e para evitar desastres sociais, está também profundamente influenciada pelas atitudes que adquirimos como crianças. [...] O êxito de uma democracia depende da participação dos cidadãos e este não é somente um assunto de "reação visceral" para viver como cidadãos ativos e deliberadores [...] A experiência e a qualidade da infância [...] tem um efeito profundo sobre as capacidades dos adultos para viver em forma exitosa na sociedade (BANCO INTERAMERICANO DE DESENVOLVIMENTO, 1999, p. 6-7).

77 Quanto ao Brasil, o documento refere que é um dos países que tem adotado o programa MIEN, com o objetivo de eliminar a desnutrição e baixo peso (BANCO INTERAMERICANO DE DESENVOLVIMENTO, 1999, p.12). 
El MIEN es importante porque se concentra en los niños más pequeños, desde el nacimiento hasta los cinco años, que tradicionalmente han sido los más difíciles de alcanzar. También es importante porque utiliza la infraestructura existente como punto de partida: los trabajadores locales de salud reciben capacitación y apoyo para ayudar a los niños ya los padres (BANCO INTERAMERICANO DE DESENVOLVIMENTO, 1999, p.11) 78. $^{7}$

Diante dos aspectos apresentados como orientações políticas aos países em desenvolvimento (entre eles o Brasil) quanto ao cuidado na primeira infância, entende-se que o conceito de cuidado expresso atualmente na Educação Infantil tem bases teóricas herdadas das orientações políticas atuais das agências multilaterais.

No caso do Brasil, o cuidar na Educação Infantil vai além da concepção de educar. Refere-se a um cuidado com interesses voltados ao desenvolvimento econômico da Nação, ao alívio da pobreza, às políticas de focalização propostas no contexto do neoliberalismo e do capital mundial. Os conceitos de educar e cuidar da infância dos países periféricos no contexto atual, na visão dessas agências internacionais, representam uma fragmentação da compreensão real da totalidade. O que elas propõem é uma educação de atendimento de caráter compensatório, com o intuito de promover uma mudança social ou uma mera manutenção social, apresentando sugestões para a solução dos problemas educacionais e sociais.

78 O MIEN é importante porque se concentra nas crianças mais pequenas, desde o nascimento até os cinco anos, que tradicionalmente têm sido os mais difíceis de alcançar. Também é importante porque utiliza a infraestrutura existente como pondo de partida: os trabalhadores locais da saúde recebem capacitação e apoio para ajudar as crianças e os pais (BANCO INTERAMERICANO DE DESENVOLVIMENTO, 1999, p.11). 
PARTE II - AS POLÍTICAS PÚBLICAS PARA A EDUCAÇÃO INFANTIL...

\subsubsection{Comissão Econômica para a América Latina (CEPAL)}

A CEPAL ${ }^{79}$ é uma das cinco comissões regionais das Nações Unidas e tem sua sede em Santiago, no Chile. Foi criada pela Resolução 106 (VI), em 1948, e começou a funcionar nesse mesmo ano. $\mathrm{O}$ objetivo dessa agência é contribuir para o desenvolvimento econômico da América Latina, coordenar as ações encaminhadas para a sua promoção e reforçar as relações econômicas dos países latinos com as demais nações do mundo. Posteriormente incorporou o Caribe no programa de desenvolvimento social.

Compõem a CEPAL trinta e três países da América Latina e Caribe, juntamente com algumas nações da América do Norte e da Europa que mantêm vínculos históricos, econômicos e culturais com a região. Ao todo, são quarenta e três paísesmembros $^{80}$, dos quais sete são associados ${ }^{81}$.

Quanto às informações históricas da Cepal, especificamente sobre a trajetória intelectual do organismo, percebe-se que a realidade econômica mundial determinou as ações e análises dos países-membros. A partir de 1990 o eixo do pensamento da organização para a região latino-americana está ligado à transformação produtiva com equidade. $O$

79 Para mais detalhes sobre a CEPAL ver site <http://www.eclac.cl>.

80 Alemanha, Antígua e Barbuda, Argentina, Bahamas, Barbados, Belice, Bolívia, Brasil, Canadá, Chile, Colômbia, Costa Rica, Cuba, Dominicana, Equador, El Salvador, Espanha, Estados Unidos, França, Granada, Guatemala, Guiana, Haiti, Honduras, Itália, Jamaica, México, Nicarágua, Países Baixos, Panamá, Paraguai, Peru, Portugal, Reino Unido da Grã Bretanha, Irlanda do Norte, República Dominicana, Saint Kitts e Nevis, São Vicente e Grandinas, Santa Lucia, Suriname, Trinidad e Tobago, Uruguai e Venezuela.

81 Anguila, Atilhas Neerlandesas, Aruba, Ilhas Virgínias Britânicas, Ilhas Virgínias dos Estados Unidos, Monte Serrat, Porto Rico. 
Políticas públicas para a educaçäo infantil no Brasil (1990-2001)

quadro 2 sintetiza os principais conjuntos de teses tomadas como ponto de partida, ou seja, como guia para um estudo sobre a obra intelectual da CEPAL entre 1948 e 1998.

\begin{tabular}{|c|c|c|c|}
\hline Elementos & \multicolumn{3}{|c|}{ Análisis histórico-estructuralista } \\
\hline $\begin{array}{l}\text { Períodos y } \\
\text { temas }\end{array}$ & $\begin{array}{l}\text { Inserción } \\
\text { internacional } \\
\text { (centro-periferia } \\
\text { y vulnerabilidad } \\
\text { externa) }\end{array}$ & $\begin{array}{l}\text { Condiciones estructurales } \\
\text { internas (económicas y } \\
\text { sociales) del crecimiento/ } \\
\text { progreso técnico, y del } \\
\text { empleo/distribución del } \\
\text { ingreso }\end{array}$ & Acción estatal \\
\hline $\begin{array}{l}\text { 1948-1960 } \\
\text { (industrialización) }\end{array}$ & $\begin{array}{l}\text { Deterioro de } \\
\text { los términos de } \\
\text { intercambio; } \\
\text { desequilibrio } \\
\text { estructural de la } \\
\text { balanza de pagos; } \\
\text { integración regional }\end{array}$ & $\begin{array}{l}\text { Proceso de } \\
\text { industrialización } \\
\text { sustitutiva; tendencias } \\
\text { perversas causadas por } \\
\text { la especialización y la } \\
\text { heterogeneidad estructural: } \\
\text { inflación estructural y } \\
\text { desempleo }\end{array}$ & $\begin{array}{l}\text { Conducir } \\
\text { deliberadamente la } \\
\text { industrialización }\end{array}$ \\
\hline $\begin{array}{l}1960 \\
\text { (reformas) }\end{array}$ & $\begin{array}{l}\text { Dependencia; } \\
\text { integración regional; } \\
\text { política internacional } \\
\text { de reducción de la } \\
\text { vulnerabilidad en } \\
\text { la periferia; sesgo } \\
\text { antiexportación } \\
\text { industrial }\end{array}$ & $\begin{array}{l}\text { Reforma agraria y } \\
\text { distribución del ingreso } \\
\text { como requisito para } \\
\text { redinamizar la economía; } \\
\text { heterogeneidad estructural; } \\
\text { dependencia }\end{array}$ & $\begin{array}{l}\text { Reformar para } \\
\text { viabilizar el } \\
\text { desarrollo }\end{array}$ \\
\hline $\begin{array}{l}1970 \text { (estilos de } \\
\text { crecimiento) }\end{array}$ & $\begin{array}{l}\text { Dependência, } \\
\text { endeudamiento } \\
\text { peligroso; } \\
\text { insuficiencia } \\
\text { exportadora }\end{array}$ & $\begin{array}{l}\text { Estilos de crecimiento, } \\
\text { estructura productiva y } \\
\text { distributiva y estructuras de } \\
\text { poder; industrialización que } \\
\text { combina el mercado interno } \\
\text { y el esfuerzo exportador }\end{array}$ & $\begin{array}{l}\text { Viabilizar el estilo } \\
\text { que lleve a la } \\
\text { homogeneidad } \\
\text { social; fortalecer } \\
\text { las exportaciones } \\
\text { industriales }\end{array}$ \\
\hline
\end{tabular}

Continuação .../ 


\begin{tabular}{|c|c|c|c|}
\hline 1980 (deuda) & Asfixia financiera & $\begin{array}{l}\text { Ajuste con crecimiento; } \\
\text { oposición a los choques } \\
\text { del ajuste, necesidad } \\
\text { de políticas de ingreso y } \\
\text { eventual conveniencia de } \\
\text { choques estabilizadores; } \\
\text { costo social del ajuste }\end{array}$ & $\begin{array}{l}\text { Renegociar la } \\
\text { deuda para ajustar } \\
\text { con crecimiento }\end{array}$ \\
\hline $\begin{array}{l}\text { 1990-1998 } \\
\text { (transformación } \\
\text { productiva con } \\
\text { equidad) }\end{array}$ & $\begin{array}{l}\text { Especialización } \\
\text { exportadora ineficaz } \\
\text { y vulnerabilidad a } \\
\text { los movimientos de } \\
\text { capitales }\end{array}$ & $\begin{array}{l}\text { Dificultades para una } \\
\text { transformación productiva } \\
\text { eficaz y para reducir la } \\
\text { brecha de la equidad }\end{array}$ & $\begin{array}{l}\text { Ejecutar políticas } \\
\text { para fortalecer la } \\
\text { transformación } \\
\text { productiva con } \\
\text { equidad }\end{array}$ \\
\hline
\end{tabular}

Quadro 2: Síntesis de Los Elementos Analíticos que Componen el Pensamiento De La Cepal ${ }^{82}$

Fonte: $\operatorname{CEPAL}(2005$, p. 7).

Ao analisar sinteticamente a influência da Cepal na década de 1990, verifica-se que o foco das recomendações políticas e econômicas aos países-membros e associados esteve pautado na estratégia de reforma para maximização dos benefícios e minimização das deficiências a médio e longo prazo, com ênfase na ideia balizadora de transformação produtiva com equidade. Nesse embate, a reforma do Estado para ampliar sua eficiência e intervenção na economia passa a ser uma recomendação política da Cepal:

Los 90s son tiempos de 'compromiso' entre la admisión de la conveniencia de que amplíen las funciones del mercado y la defensa de la analices y las proposiciones de políticas se orienten a los temas que privilegie la CEPAL, o sea, el progreso técnico y la distribución del ingreso, abriendo el

82 Ver a tradução anexo. 
Políticas públicas para a Educaçäo Infantil no Brasil (1990-2001)

diálogo a derecha e izquierda del espectro teórico internacional ${ }^{83}$ (COMISSÃO ECONÔMICA PARA A AMÉRICA LATINA, 2005, p. 12).

A proposta de transformação produtiva com equidade da CEPAL representou o momento em que essa agência impulsionou e propagou o processo de reformas. Naquela década a CEPAL desenvolveu uma produção teórica em quatro temas: Regionalismo aberto, Fragilidade financeira da região, Ajuste fiscal e Desenvolvimento sustentável.

1) Em 'Regionalismo aberto' a Comissão destaca as vantagens da simultaneidade entre abertura comercial da América Latina e o resto do mundo e a intensificação do comércio intrarregional através dos esquemas de integração vigentes.

2) Em 'Fragilidade financeira da região' o estudo da Cepal adverte quanto ao capital volátil e assinala os efeitos perversos das entradas de capital que não são seguidas de aumento correspondente da inversão produtiva e da competitividade para exportar.

3) Em 'Ajuste fiscal' recomenda a elevação da produtividade, o controle do gasto público, a transparência, a promoção da equidade e a institucionalidade democrática.

4) Em 'Desenvolvimento sustentável' analisa especialmente o impacto das políticas públicas nos países, as mudanças nas negociações comerciais internacionais $\mathrm{Em}$ face da nova visão sobre o meio ambiente e as fontes de financiamento para o desenvolvimento sustentável (COMISSÃO ECONÔMICA PARA A AMÉRICA LATINA, 2005, p.13-14).

83 Os anos 90 são o tempo de "compromisso" entre a admissão da conveniência que ampliam a funcionalidade do mercado e a defesa das análises e propostas que são voltadas para as questões que favorece a CEPAL, isto é, o progresso técnico e a distribuição de renda, abrindo o diálogo entre a direita e a esquerda do espectro teórico internacional (COMISSÃO ECONÔMICA PARA A AMÉRICA LATINA, 2005, p. 12). 
PARTE II - AS POLÍTICAS PÚBLICAS PARA A EDUCAÇÃO INFANTIL...

A produção recente da Cepal, no fim da década de 1990, focaliza

[...] las profundas asimetrías en el orden global, señalando la forma como las condiciones de inserción de América Latina y el Caribe en ese orden le afectan negativamente en términos productivos y financieros, y provocan fuerte inestabilidad macroeconómica, bajo dinamismo económico y efectos sociales muy adversos. Asimismo, la CEPAL ha profundizado sus advertencias y planteamientos críticos sobre los impactos potenciales y efectivos de las reformas sobre las economías de la región, en consonancia con el creciente reconocimiento internacional sobre sus fragilidades, y ha postulado la necesidad de buscar una globalización más equilibrada, y de 'reformar las reformas' (COMISSÃO ECONÔMICA PARA A AMÉRICA LATINA, 2005, p.15) ${ }^{84}$

As questões expostas nesta unidade sobre o papel das agências internacionais mostram que, apesar das diferenças quanto às funções específicas das agências e de seu foco de localização, todas expressam a meta das orientações políticas aos países que no âmbito mundial comandam os rumos do capital internacional. A educação, pauta sempre presente nas agendas dessas agências, é tida como um meio de conscientização sobre as políticas neoliberais de ajuste.

$84[\ldots]$ as profundas assimetrias na ordem global, assinalando a forma como as condições de investimentos da América Latina e do Caribe nessa ordem afetam negativamente em termos produtivo e financeiro, e provocam forte instabilidade macroeconômica, baixo dinamismo econômico e efeitos sociais muito adversos. Assim mesmo, a CEPAL tem aprofundado suas advertências e críticas quanto aos impactos potenciais e efeitos das reformas sobre as economias da região, em consonância com o crescente reconhecimento internacional sobre suas fragilidades, e tem postulado a necessidade de buscar uma globalização mais equilibrada, e de "reformar as reformas” (COMISSÃO ECONÔMICA PARA A AMÉRICA LATINA, 2005, p. 3). 
Políticas públicas para a Educaçäo infantil no Brasil (1990-2001)

\subsection{EDUCAÇÃO INFANTIL E OS DOCUMENTOS OFICIAIS DO MEC}

Ao ressaltar as principais mudanças no contexto da legislação educacional, especificamente no que tange à Educação Infantil, tem-se como objetivo estabelecer uma compreensão sobre a reforma educacional no panorama político estabelecido na fase de mundialização do capital sob a influência do neoliberalismo e das já comentadas orientações políticas emanadas das organizações internacionais .

\subsubsection{A Educação Infantil na Constituição Federal de 1988}

A Constituição Federal aprovada em 05/10/1988, ao enumerar os direitos sociais dos trabalhadores, inclui:

CF/1988. Artigo 7, inciso XXV

"[...] assistência gratuita a filhos e dependentes desde o nascimento até seis anos de idade em creches e pré-escolas".

\section{CF/1988. Artigo 208, inciso IV}

"[...] atendimento em creche e pré-escola às crianças de zero a seis anos de idade".

Pela primeira vez no Brasil uma constituição federal referiu-se às garantias da efetivação do dever do Estado para com a Educação Infantil. Este é um dos aspectos centrais para 
PARTE II - AS POLÍTICAS PÚBLICAS PARA A EDUCAÇÃO INFANTIL...

essa primeira etapa da educação, pois deixa claros a obrigação do Estado de oferecer e o direito da criança de zero a seis anos de receber essa educação em creches e pré-escolas. Para Corrêa (2002, p.19), isso significa, no plano jurídico, que

[...] uma nova lógica se impõe, dado que qualquer família que deseje colocar sua criança numa creche poderá recorrer a promotoria pública para que esta, baseada e fundamentada na Constituição Federal, acione o Estado a fim de que este cumpra seu dever.

Ao garantir esse novo direito, que é a Educação Infantil, a CF de 1988 impõe ao Estado também um novo dever. Esse direito representou uma conquista das discussões e reivindicações dos movimentos sociais em geral.

Corrêa (2002) sugere que os movimentos das mulheres organizados após a inserção da maior parte delas no mercado de trabalho, juntamente com as reivindicações da classe média, passaram a procurar as instituições coletivas de atendimento à criança de zero a seis anos de idade.

Constata-se também que a Constituição Federal incorporou algo que estava presente no movimento da sociedade, visto que o processo constituinte deu-se em meio a essas forças, recebendo propostas que expressavam tal movimento. Segundo Peroni (2003, p. 19),

Durante o movimento da Constituição, quando se discutiam os pontos a serem abarcados pela nova carta magna do Brasil, o engajamento dos profissionais da área por meio de associações representativas foi bastante intenso no sentido de conquistar direitos para a criança de zero a seis anos. Esta mobilização contou com o apoio de outros setores da sociedade civil organizada, tais como movimentos de mulheres do fórum em defesa da Criança e do Adolescente 
Políticas públicas para a Educaçäo Infantil no Brasil (1990-2001)

(DCA) e do Grupo de Ação pela Vida, entre outros $^{85}$.

A Constituição não trata apenas do direito a essa etapa básica, pois outros pontos fazem referência à educação como um todo, atingindo também a Educação Infantil, como estabelece o artigo abaixo:

\section{CF/1988. Artigo 205}

A educação, direito de todos e dever do Estado e da família, será promovida e incentivada com a elaboração da sociedade, visando ao pleno desenvolvimento da pessoa, seu preparo para o exercício da cidadania e sua qualificação para o trabalho.

Esse artigo da CF indica que a educação é "direito de todos". O relevante para a Educação Infantil são as ideias de direito ao acesso para todos e os objetivos de pleno desenvolvimento da pessoa, como preveem os incisos I e VII do artigo 206:

\section{CF/1988, Artigo 206}

I - igualdade de condições para o acesso e permanência na escola.

VII - garantia de padrão de qualidade.

85 O FNDEP - Fórum Nacional em Defesa da Escola Pública - como movimento social, surgiu em 1986 em função de articulações realizadas objetivando a elaboração de uma carta constitucional para o país. O fórum foi oficialmente lançado em Brasília, em 9 de abril de 1987, na Campanha Nacional em Defesa da Escola Pública e Gratuita, denominado inicialmente, de Fórum da Educação na Constituinte em Defesa do Ensino Público e Gratuito. O fórum contou inicialmente com 15 entidades, e, apesar da diversidade de interesses, havia dois núcleos congregantes que as articulavam: a defesa da escola pública e a posição político-partidária de oposição ao regime militar (PERONI, 2003, p.19). 
PARTE II - AS POLÍTICAS PÚBLICAS PARA A EDUCAÇÃO INFANTIL...

Ao tratar dos princípios do ensino, a CF estabelece, no inciso I do artigo em epígrafe, o direito de acesso e permanência na escola para todas as crianças, o que pode ser mais uma forma de pressionar o Estado a ampliar a oferta de vagas e as diversas esferas da Educação a supervisionar seus sistemas de ensino e corrigi-los quando estes dificultam o exercício desse direito.

Quanto ao inciso VII, entende-se que garantir padrão de qualidade é condição que jamais se pode perder de vista, visto que na história da Educação Infantil brasileira a marca de sua origem e de sua expansão sempre foi a precariedade. Quantidade e ampliação precisam combinar-se com qualidade na oferta e acesso a todos que o queiram.

\section{CF/1988, artigo 209}

O ensino é livre à iniciativa privada, atendidas as seguintes condições:

I - cumprimento das normas gerais da educação nacional;

II - autorização e avaliação de qualidade pelo Poder Público.

Nesse artigo há um importante avanço. Na medida em que há expansão das instituições de Educação Infantil, faz-se necessária uma efetiva fiscalização, para impedir que instituições privadas atendam crianças na faixa do zero a seis anos de idade sem nenhuma preocupação com a qualidade do serviço, pois em muitas delas os espaços são inadequados e há falta de qualificação e formação mínima dos que atuam nesses espaços.

A CF estabelece percentuais mínimos de gastos da receita de impostos com educação para cada ente federativo, a saber: a União deve gastar 18\%, enquanto os estados federados, o Distrito Federal e os municípios devem investir no mínimo 25\% de sua arrecadação. 
Políticas públicas para a Educaçäo Infantil no Brasil (1990-2001)

Uma questão polêmica é o que prevê o artigo 211:

CF/1988, Artigo 211

A União, os Estados, o Distrito Federal e os Municípios organizarão em regime de colaboração seus sistemas de ensino.

$\S 1^{\circ}$ - A União organizará o sistema federal.

Compreende-se que o termo "em regime de colaboração" denota que nenhuma esfera terá responsabilidade exclusiva por quaisquer deveres relativos à educação pública. Na Emenda Constitucional N. ${ }^{\circ} 14$ foi dada nova redação ao parágrafo $2^{\circ}$, o qual recomenda uma política de enxugamento do aparelho do Estado - obviedade decorrente de orientações políticas advindas da estratégia de focalização.

Por outro lado, é nessa mesma emenda que se encontra pela primeira vez o termo Educação Infantil, que compreende creches (zero a três anos) e pré-escolas (quatro a seis anos). Fica evidente que foi entregue aos municípios a responsabilidade pelo atendimento em creches e pré-escolas, o que torna explícita a concepção de um Estado descentralizador, a qual se inspira nos documentos do BM e de outros órgãos ou organizações.

Essa emenda altera também o disposto no artigo 60 das Disposições Constitucionais Transitórias e dispõe sobre a criação do que denominou de Fundo de Manutenção e Desenvolvimento do Ensino Fundamental e de Valorização do Magistério (FUNDEF), determinando que, no mínimo, 60\% dos recursos referidos no caput do artigo 212 sejam destinados ao Ensino Fundamental. Caberia somente aos municípios a responsabilidade pela oferta de Educação Infantil, e estes, por 
PARTE II - AS POLÍTICAS PÚBLICAS PARA A EDUCAÇÃO INFANTIL...

falta de recursos, acabaram por limitar suas vagas nas creches e pré-escolas, as quais nem sempre podem receber todas as crianças.

Ultimamente uma nova emenda constitucional modificou o artigo 212 da Constituição Federal e deu nova redação aos artigos 60 e 76 das Disposições Transitórias. Foi encaminhada pelo MEC a proposta do Fundo de Manutenção e Desenvolvimento da Educação Básica e de valorização dos profissionais da Educação (FUNDEB). Segundo as diretrizes e justificativas do novo fundo, era necessário:

- criar um fundo único para cada unidade de Federação;

- excluir impostos administrativos estaduais e os do Fundef (Fundo de Participação dos Municípios e dos Estados);

- repartir por matrícula no ensino básico, diferenciando por etapa (Infantil, Fundamental, médio) e especificidade (Educação de jovem e adultos, especial, rural, etc), mas autoriza o gasto com universidade; as matrículas em creches seriam consideradas, mas com corte de renda;

- excluir progressivamente os inativos;

- revincular de forma progressiva recursos da educação desvinculados (Desvinculação da Receita da União - DRU), parte dos quais destinar-se-á complementar o per capita dos estados mais pobres;

- reformular o salário-educação, admitindo o gasto em todo o ensino básico;

- estabelecer como peso para o ensino fundamental o per capita da época da promulgação da emenda constitucional que cria o Fundeb; 
- estabelecer recursosadicionaisdaUniãocomocontrapartida, além de saldar eventuais débitos do Fundef;

- controlar a efetividade do gasto por meio de certificação de frequência e qualidade (BRASIL, 2004).

A proposta do FUNDEB foi aprovada pelo Congresso Nacional e a partir da sua ampliação a Educação Infantil começou a receber verba específica, conforme o número de matrícula e ponderação específica a partir do primeiro ano de vigência do FUNDEB, sendo as seguintes especificações: I - creche - 0,80 (oitenta centésimos); II - pré-escola - 0,90 (noventa centésimos) (Art. 36).

\subsubsection{Estatuto da Criança e do Adolescente (ECA) - Lei N.ㅇ 8.069/90}

O ECA foi elaborado e sancionado em forma de lei logo após a promulgação da Constituição Federal de 1988, e estabeleceu garantias e direitos para a infância e a adolescência. Assim, a Constituição de 1988 e o ECA mudaram o panorama da criança e do adolescente no Brasil, especialmente no tocante às políticas sociais, pois foi a partir desses diplomas que foram legalmente reconhecidos esses direitos, os quais podem ser exercidos junto à família, à sociedade e ao Estado. Os direitos assegurados pelo Eca constituem a chamada proteção integral, pela qual as crianças e adolescentes devem ser protegidos juridicamente nos aspectos, saúde, a educação, transporte, lazer e cultura.

Nos artigos $3^{\circ}$ e $4^{\circ}$ tem-se uma dimensão da importância conferida a esses dois grupos etários, o das criança e o dos adolescentes, como se vê a seguir. 


\section{ECA/1990, Artigo $3^{\circ}$}

Art. $3^{\circ}$ - A criança e o adolescente gozam de todos os direitos fundamentais inerentes à pessoa humana, sem prejuízo da proteção integral de que trata esta Lei, assegurando-se-lhes, por lei ou por outros meios, todas as oportunidades e facilidades, a fim de lhes facultar o desenvolvimento físico, mental, moral, espiritual e social, em condições de liberdade e de dignidade.

Artigo $4^{\circ}$ - É dever da família, da comunidade, da sociedade em geral e do Poder público assegurar, com absoluta prioridade, a efetivação dos direitos referentes à vida, à saúde, à alimentação, à educação, ao esporte, ao lazer, à profissionalização, à cultura, à dignidade, ao respeito, à liberdade e à convivência familiar e comunitária.

Parágrafo único - A garantia de prioridade compreende:

a) primazia de receber proteção e socorro em qualquer circunstância;

b) precedência do atendimento nos serviços públicos ou de relevância pública:

c) destinação privilegiada de recursos públicos nas áreas relacionadas com a proteção da família e à juventude.

Nesse aspecto, a ideia de garantia de prioridade se faz presente também no artigo 53, apresentado abaixo.

\section{ECA/1990, Artigo 53}

Art. 53- A criança e o Adolescente têm direito à educação, visando ao pleno desenvolvimento de sua pessoa, preparo para o exercício da cidadania e qualificação para o trabalho, assegurando-lhes: I - igualdade de condições para o acesso e permanência na escola; II - direito de ser respeitado por seus educadores; III - direito de contestar critérios avaliativos, podendo recorrer às instâncias escolares superiores; IV - direito de organização e participação em entidades estudantes; $\vee$ - acesso à escola gratuita próxima de sua residência; Parágrafo Único: É direito dos pais ou responsáveis ter ciência do processo pedagógico, bem como participar da definição das propostas educacionais.

Ao tratar sobre a educação, o ECA define que esta deve assegurar, entre outros (só para citar uma "sutileza"), o "direito 
Políticas públicas para a Educaçäo Infantil no Brasil (1990-2001)

de ser respeitado por seus educadores". Segundo Corrêa (2002, p.24), para a Educação Infantil em especial, em face das

[...] limitações de autodefesa das crianças em razão de sua pouca idade, isto é absolutamente relevante. Sabe-se que, em algumas instituições, práticas como os castigos de toda natureza, algumas vezes físicos garante, evidentemente, as sua superação, mas representa, sem dúvida, um poderoso instrumento de repressão a tais práticas.

No artigo 54 o ECA, especifica a Educação Infantil ao determinar que é dever do Estado assegurar: "IV - atendimento em creche e pré-escola às crianças de zero a seis anos de idade". Também no artigo 4० o ECA estabelece como dever do Estado garantir atendimento gratuito em creches e pré-escolas às crianças de zero a seis anos de idade, No artigo 11 incumbe o município de oferecer a Educação Infantil, mas ressalta que a prioridade é o Ensino Fundamental:

"V - oferecer a educação infantil em creches e pré-escolas e, com prioridade, o Ensino Fundamental, permitida a atuação em outros níveis de ensino somente quando estiverem atendidas plenamente as necessidades de sua área de competência e com recursos acima dos percentuais mínimos vinculados pela Constituição Federal à manutenção e desenvolvimento do ensino".

O ECA enfatiza e garante amplamente a Educação Infantil para todas as crianças, pois em vários de seus artigos consta a ideia de garantia de prioridade ao atendimento a esses direitos; mas na prática isto ainda está muito longe de ser alcançado, pelo descaso do Estado em cumprir suas metas, deveres e obrigações decorrente de suas políticas neoliberais e de interesses de classes antagônicas, utilizando-se de mediadas 
PARTE II - AS POLÍTICAS PÚBLICAS PARA A EDUCAÇÃO INFANTIL...

sutis, como descentralizar e focalizar, culpabilizar o indivíduo para desviar as atenções e responsabilizar os outros por aquilo que ele mesmo deve oferecer.

\subsubsection{Lei de Diretrizes e Bases da Educação - LDB N.으 9.394/96}

A atual Lei de Diretrizes e Bases da Educação Nacional, também conhecida como Lei Darcy Ribeiro ${ }^{86}$, foi aprovada pelo Congresso Nacional em 17 de dezembro de 1996, promulgada em 20 de dezembro de 1996 e publicada no Diário Oficial no dia 23 de dezembro de $1996^{87}$. Durante o governo de Fernando Henrique Cardoso passou por um processo de discussão que durou quase dez anos ${ }^{88}$, durante os quais as diferentes forças e segmentos sociais e econômicos se enfrentaram em defesa de interesses antagônicos (SAVIANI, 1999). Se no aspecto legal a LDB representa conquistas

86 Darcy Ribeiro (1922-1997) nasceu em Montes Claros, MG. Teve uma participação intensa na política e na educação brasileira, destaque à participação, juntamente com Anísio Teixeira, na defesa da escola pública e na criação da Universidade de Brasília, da qual foi o primeiro reitor. Foi ministro da Educação no governo de Jânio Quadros (1961) e chefe da casa civil no governo João Goulart, tendo sido um dos líderes das reformas estruturais. Com o golpe militar em 1964, teve seus direitos políticos cassados e foi exilado. Viveu em vários países da América Latina. Em 1990 foi eleito senador da República. Ver <http://www.academia.org.br/ imortais/cads11/darcy.htm>.

87 Cf. Saviani (1999 - prefácio).

88 O início de sua formulação foi em 1988, antes mesmo do Plano Decenal, ficando oito anos tramitando no Congresso Nacional. Paralelamente ao projeto que tramitava no Congresso, o senador Darcy Ribeiro apresentou um novo dispositivo da Lei que foi aprovado. A aprovação da LDB, feita de forma atropelada, foi interpretada por muitos como um grande golpe nas políticas para a educação pública, pois o Congresso deixou de lado o debate nacional e privilegiou um texto que visa, em grande parte, à legalização das políticas educacionais do governo (PERONI, 2003, p. 79-87). 
Políticas públicas para a Educaçäo Infantil no Brasil (1990-2001)

históricas, por outro lado apresenta limitações e perdas para as camadas populares no tocante à educação.

$\mathrm{Na}$ LDB, a Educação Infantil ganha especificidade quando é referida como a primeira etapa da Educação Básica. No artigo 21 da LDB N. 9 9394/96 está redigido o que anteriormente havia sido estabelecido na Constituição Federal de 1988, como se vê abaixo.

\section{LDB n० 9394/96}

Art. 21- A educação compõe-se de: I - Educação Básica, formada pela educação infantil, ensino fundamental e ensino médio".

Cumpre observar que na prática isto não aconteceu, pois o Ensino Fundamental foi priorizado em relação aos outros níveis de ensino, o que revela a estreita sintonia com os projetos do Banco Mundial.

\section{LDB $n^{\circ} 9394 / 96$}

Art. 29 - A Educação Infantil, primeira etapa da Educação Básica, tem como finalidade o desenvolvimento integral da criança até seis anos de idade, em seus aspectos físicos, psicológicos intelectuais e sociais, completando a ação da família e da comunidade.

Art. 31 - Na Educação Infantil a avaliação far-se-á mediante o acompanhamento e registro do seu desenvolvimento, sem o objetivo de promoção, mesmo para o acesso ao ensino fundamental.

Sobre os artigos acima, Corrêa (2002) comenta que ambos são importantes, pois expressam uma nova visão relativa às necessidades da criança de zero a seis anos, prevendo que a escola deve ocupar-se de seu desenvolvimento 
PARTE II - AS POLÍTICAS PÚBLICAS PARA A EDUCAÇÃO INFANTIL...

global e configurando a educação como um complemento da ação da família e da sociedade, e não como uma substituição destas.

Por outro lado, segundo a autora, o artigo 31 dessa lei inibe práticas avaliativas absurdas que até bem pouco tempo atrás eram ainda comuns em algumas regiões do país, como as classes de alfabetização nas quais crianças eram retidas mesmo após completarem os sete anos, caso ainda não estivessem alfabetizadas.

No que tange à gratuidade do ensino na Educação Infantil, no inciso IV do artigo $4^{\circ}$, que trata dos deveres do Estado, a LDB inclui o termo "gratuito", que reforça esse dever:

\section{LDB $n^{\circ} 9394 / 96$}

Art. $4^{\circ}-\mathrm{IV}:[\ldots]$ atendimento gratuito em creches e pré-escolas às crianças de zero a seis anos de idade.

A expressão "gratuito" não apareceu na Constituição Federal, tampouco no ECA. Quanto à discussão sobre a idade em que a criança deve iniciar o Ensino Fundamental, encontramos a exceção à criança de seis anos quando a lei coloca o termo "facultativamente":

\section{LDB $n^{\circ} 9394 / 96$}

Art. 87 - parágrafo $3^{\circ}$ - cada município e, supletivamente, o Estado e a união, deverá: "[...] matricular todos os educandos a partir dos sete anos de idade e, facultativamente, a partir dos seis anos no ensino fundamental.

Acerca das incumbências da União, a lei estabelece: 
Políticas públicas para a Educaçäo Infantil no Brasil (1990-2001)

\section{LDB $n^{\circ} 9.394 / 96$}

Art.9º - é dever estabelecer, em colaboração com os Estados, o Distrito Federal e os municípios, competências e diretrizes para a educação infantil, o ensino fundamental e o ensino médio, que nortearão os currículos e seus conteúdos mínimos, de modo a assegurar formação básica comum.

Percebe-se que a LDB demonstrou compatibilidade com o cenário político e econômico, possibilitando ao governo implementar as reformas nas políticas educacionais, as quais se direcionam para um projeto neoliberal de educação. Desta forma, afirma-se que a LDB possui um caráter minimalista e características neoliberais. A esse respeito Saviani (1999, p. 201) observa:

Com efeito, em todas as iniciativas de política educacional, apesar de seu caráter localizado e de aparência de autonomia e desarticulação entre elas, encontramos um ponto comum que atravessa todas elas: o empenho em reduzir custos, encargos e investimentos públicos buscando senão transferilos, ao menos dividi-los (parceria é a palavra da moda com a iniciativa privada e as organizações não governamentais.

Outro aspecto a destacar é que a responsabilidade pela educação passou a ser dividida com o setor privado (Terceiro Setor $\left.{ }^{89}\right)$, ONGs e a família. As prioridades no artigo $2^{\circ}$ da LDB estão invertidas em relação à Constituição, como se vê abaixo.

89 Sendo o primeiro setor o governo e o segundo setor o setor privado; o termo terceiro setor se refere ao setor privado, colaborando com a responsabilidade que seria do primeiro setor. Portanto, com a falência do Estado, o setor privado começou a ajudar nas questões sociais, através das inúmeras instituições que compõem o Terceiro Setor, ou seja, as organizações "sem fins lucrativos” e não-governamentais, que têm como objetivo gerar serviços de caráter público. 
PARTE II - AS POLÍTICAS PÚBLICAS PARA A EDUCAÇÃO INFANTIL..

\section{LDB $n^{\circ} 9394 / 96$}

Art. $2^{\circ}$ - A educação, dever da família e do estado, inspirada nos princípios de liberdade e nos ideais de solidariedade humana, tem por finalidade o pleno desenvolvimento do educando, seu preparo para o exercício da cidadania e sua qualificação para o trabalho.

Fica constatado que ao inverter a ordem das palavras a LDB modifica o sentido da política para o setor, colocando a família como a primeira responsável pela educação, e não o Estado, como prevê a Constituição, fato que evidencia a influência das diretrizes neoliberais ao eximirem o Estado de suas responsabilidades sociais, transferindo-as para a esfera privada e a sociedade civil.

\subsubsection{Plano Nacional de Educação - PNE, Lei N.으 $10.172 / 2001$}

A Lei de Diretrizes e Bases da Educação N. $9.394 / 96$ e a Constituição Federal de 1988 estabeleceram a obrigatoriedade de o Ministério de Educação (MEC) elaborar o Plano Nacional de Educação (PNE). Essa obrigatoriedade se encontra nos seguintes artigos da LDB:

Art. 9० - A união incumbir-se-á de:

I - elaborar o Plano Nacional de Educação, em colaboração com os Estados, o Distrito Federal e os Municípios;

Art. 870 - É instituída a Década da Educação, a iniciar-se um ano a partir da publicação desta Lei.

Parágrafo 1o - A União, no prazo de um ano a partir da publicação desta Lei encaminhará, ao Congresso nacional, o Plano nacional de educação, 
Políticas públicas para a Educaçäo Infantil no Brasil (1990-2001)

com diretrizes e metas para os dez anos seguintes, em sintonia com a Declaração Mundial sobre Educação para Todos.

No artigo 87 é possível observar que a elaboração do PNE é reservada ao MEC, ficando eliminado o Fórum Nacional de Educação como órgão participativo na definição das políticas educacionais. Com isso a sociedade ficou impedida de participar dos debates, o que contribui para atender às exigências das agências internacionais, ao pontuar que o PNE deve estar em sintonia com a Declaração Mundial sobre Educação para Todos (Declaração de Jomtien). ${ }^{90}$

$\mathrm{Na}$ Constituição Federal de 1988 essa obrigatoriedade se encontra no artigo 214, que assim dispõe:

Art. 214 - A lei estabelecerá o Plano Nacional de Educação, de duração plurianual, visando à articulação e ao desenvolvimento do ensino em seus diversos níveis e à integração das ações do Poder Público que conduzam à:

I - erradicação do analfabetismo

II - universalização do atendimento escolar

III - melhoria da qualidade do ensino

IV - formação para o trabalho

V - promoção humanística, científica e tecnológica do País.

(BRASIL, 1988, p.177)

90 Foi a partir da Conferência Mundial de Educação Para Todos, realizada em Jomtien, na Tailândia, em 1990, que se estabeleceu o conceito de Educação Básica como promotora do desenvolvimento dos países periféricos. Essa Conferência foi patrocinada pela Organização das Nações Unidas para a Educação, Ciências e Cultura - UNESCO, pelo Programa das Nações Unidas para o Desenvolvimento, pelo Fundo das Nações Unidas para a Infância - UNICEF e pelo Banco Mundial. Reuniram-se cerca de 1500 participantes de 155 países. Os 155 governos presentes assinaram o compromisso de garantir uma Educação Básica de qualidade para crianças, jovens e adultos, reforçando o fundamento de uma Educação Básica voltada para o desenvolvimento humano (WORLD CONFERENCE ON EDUCATION FOR ALL, 1990). 
PARTE II - AS POLÍTICAS PÚBLICAS PARA A EDUCAÇÃO INFANTIL...

O PNE originou-se de duas propostas apresentadas à Câmara dos Deputados: uma do Poder Executivo e uma da sociedade civil, esta última elaborada no $1^{\circ}$ e $2^{\circ}$ CONEDs Congressos Nacionais de Educação. A primeira, de n. ${ }^{\circ}$ 4173/98, elaborada por uma equipe do governo, reforçava a continuidade das políticas voltadas para a

[...] máxima centralização, particularmente na esfera federal, da formulação e da gestão política educacional, com o progressivo abandono, pelo estado, das tarefas de manter e desenvolver o ensino, transferindo-as, sempre que possível, para a sociedade (VALENTE; ROMANO, 2002, p. 99).

A segunda, de n. ${ }^{\circ}$ 4155/98, foi apresentada pelo deputado Ivan Valente. Sua reivindicação básica era

[...] o fortalecimento da escola pública estatal e a plena democratização da gestão educacional, como eixo do esforço para se universalizar a Educação Básica. [mas] Isso implicaria propor objetivos, metas e meios audaciosos, incluindo a ampliação do gasto público total para a manutenção e o desenvolvimento do ensino público (VALENTE; ROMANO, 2002, p. 98).

Essas duas propostas poderiam ser contempladas como uma possibilidade de se iniciar um debate acerca da elaboração do PNE; porém isto não aconteceu, pois o presidente Fernando Henrique Cardoso definiu o plano do governo como anexo ao plano da sociedade brasileira. Sua aprovação ocorreu em 9 de janeiro de 2001, com um texto substituto elaborado pelo deputado Nelson Marchesan, na forma da Lei N. ${ }^{\circ}$ 10.172, vetando os artigos considerados pela sociedade como os mais relevantes, como as diretrizes, as metas e os objetivos. Em relação 
Políticas públicas para a Educaçäo Infantil no Brasil (1990-2001)

ao texto aprovado, Valente e Romano (2002, p. 99) assim se posicionam:

\begin{abstract}
O substitutivo (que se tornou o texto-base da lei tem conteúdo peculiar: ele é um escrito teratológico (espécie de Frankenstein) que simula o diálogo com as teses geradas pela mobilização social (sobretudo no diagnóstico da situação educacional), mas adota a política do Governo FHC nas diretrizes, nos objetivos e nas metas. Estes últimos pontos são o que, de fato, possui relevância estratégica num Plano.
\end{abstract}

Sobre o PNE aprovado, Valente e Romano (2002, p.105) asseveram que o próprio presidente Fernando Henrique Cardoso comunicou que quem orientou a sua posição sobre a matéria foi "[...] a área econômica do governo e não os responsáveis pela educação”. Desta forma, entende-se que o PNE teve sua elaboração pautada nas políticas que vinham sendo implementadas pelo MEC sob a orientação das políticas mundiais para o desenvolvimento sustentável da economia.

O PNE está em consonância com a Constituição Federal, com a LDB e com os compromissos firmados pelo Brasil. Entre esses compromissos, dizem respeito mais diretamente à educação:

- o compromisso da Conferência de Dakar sobre a Educação para Todos, promovida pela Unesco, em maio de 2000;

- a Declaração de Cochabamba, dos Ministros da Educação da América Latina e Caribe, sobre Educação para Todos (2000);

- a Declaração de Hamburgo, sobre a Educação de adultos (1997);

- a Declaração de Paris, sobre a Educação Superior (1998);

- a Declaração de Salamanca, sobre necessidades especiais de educação (1994); 
PARTE II - AS POLÍTICAS PÚBLICAS PARA A EDUCAÇÃO INFANTIL...

- os documentos das Nações Unidas e da Unesco sobre os direitos humanos e a não-discriminação (BRASIL, 2001, p. 16).

Ao apresentar o processo de elaboração do PNE e constatar as influências neoliberais, os interesses econômicos nele contidos e o descaso do Estado em relação a ser esse plano discutido e elaborado no âmbito educacional, ressaltam-se, a seguir, as constantes referências do PNE à Educação Infantil.

O PNE estabelece um conjunto de vinte e seis objetivos e metas (a meta 22 foi vetada ${ }^{91}$ ) para a Educação Infantil, os quais, de forma geral, tratam, entre outras, das seguintes questões: ampliação da oferta de creches e pré-escolas; elaboração de padrões mínimos de qualidade e infraestrutura para o funcionamento adequado das instituições de educação infantil; autorização de funcionamento dessas instituições; formação dos profissionais da área; garantia da alimentação escolar para as crianças atendidas nos estabelecimentos públicos e conveniados; fornecimento de materiais adequados às faixas etárias; estabelecimento de padrões de qualidade como referência para a supervisão; controle, avaliação e aperfeiçoamento da educação infantil.

Todos esses objetivos e metas têm custos, portanto têm também reflexos sobre o financiamento da área. Neste sentido, observa-se que o PNE explicita ainda os objetivos/

91 Meta 22: ampliar o programa de garantia de Renda Mínima associado a ações socioeducativas, de sorte a atender, nos três primeiros anos do Plano, $50 \%$ das crianças de 0 a 6 anos que se enquadram nos critérios de seleção da clientela e 100\% até o sexto ano. Pinto (2002, p. 110), ao analisar os diversos vetos nos níveis de ensino, chama a atenção ao fato de essa postura impedir o desenvolvimento de "[...] todos os mecanismos que viabilizariam financeiramente, sem um comprometimento maior da qualidade [...] de uma forma geral, foram vetados todos os itens que implicassem um aporte adicional de recursos, por parte do governo federal, como se fosse possível atender o seu conjunto de metas sem a alteração dos valores atualmente gastos com o ensino no Brasil". 
Políticas públicas para a Educaçäo Infantil no Brasil (1990-2001)

metas específicos (metas 20, 21, 23 e 25) relativos à questão do financiamento da Educação Infantil. São elas:

\section{PNE Lei $n^{\circ} 10.172 / 2001$}

Promover debates com a sociedade civil sobre o direito dos trabalhadores à assistência gratuita a seus filhos e dependentes em creches e pré-escolas, estabelecido no art. $7^{\circ} \mathrm{XXV}$, da Constituição Federal. Encaminhar ao Congresso Nacional projeto de lei visando à regulamentação daquele dispositivo (Meta 20).

Assegurar que, em todos os Municípios, além de outros recursos municipais os $10 \%$ dos recursos de manutenção e desenvolvimento do ensino não vinculados ao FUNDEF sejam aplicados, prioritariamente, na educação infantil (Meta 21).

Realizar estudos sobre custo da educação infantil com base nos parâmetros de qualidade, com vistas a melhorar a eficiência e garantir a generalização da qualidade do atendimento (Meta 23).

Exercer a ação supletiva da União e do Estado junto aos Municípios que apresentem maiores necessidades técnicas e financeiras, nos termos dos artigos 30, VI e 211, parágrafo $1^{\circ}$, da Constituição Federal (Meta 25) (BRASIL, 2001, p. 44-45).

Dentre os objetivos/metas do Plano Nacional de Educação Infantil deve-se ressaltar o que trata da ampliação da oferta, pelo seu impacto sobre os demais objetivos, especialmente sobre a questão do financiamento. Prevê o PNE, no primeiro objetivo/ meta:

\section{PNE Lei $n^{\circ} 10.172 / 2001$}

Ampliar a oferta de educação infantil de forma a atender, em cinco anos, a $30 \%$ da população de até 3 anos de idade e $60 \%$ da população de 4 a 6 anos (ou 4 e 5 anos) e, até o final da década, alcançar a meta de $50 \%$ das crianças de 0 a 3 anos e 80\% das de 4 e 5 anos (Meta 1) (BRASIL, 2001, p. 42). 
PARTE II - AS POLÍTICAS PÚBLICAS PARA A EDUCAÇÃO INFANTIL...

Ao analisar o PNE, salienta-se que o estabelecimento dessas metas específicas para as duas faixas de idade (zero a 3 anos e 4 a 6 anos) é justificado, no Plano, pela história do atendimento a essas faixas etárias no Brasil, com o predomínio da área de assistência social para as crianças menores, como se vê abaixo.

\section{PNE Lei $n^{\circ} 10.172 / 2001$}

É preciso analisar separadamente as faixas etárias de 0 a 3 anos e de 4 a 6 anos, porque foram grupos tratados diferentemente, quer nos objetivos, quer por instituições que atuaram nesse campo, sejam públicas ou privadas. A primeira faixa esteve predominantemente sob a égide da assistência social e tinha uma característica mais assistencial, como cuidados físicos, saúde, alimentação (BRASIL, 2001, p. 37).

Assim sendo, as metas expostas no PNE significam, em termos de expansão de matrícula, um impacto financeiro no tocante ao princípio da equidade. Este termo é entendido como igualdade de oportunidades de acesso, de tratamento e de resultados, e se refere ao acesso à educação com iguais oportunidades de ingresso e à distribuição das possibilidades de obter uma educação de qualidade:

\footnotetext{
$\mathrm{O}$ acesso equitativo à educação significa acesso aos conhecimentos socialmente significativos. A novidade diante do debate internacional é que a equidade não é mais analisada simplesmente em termos da cobertura, mas centra-se agora na qualidade da oferta e na eficácia das estratégias aplicadas para resolver o problema dos excluídos do ensino e da capacitação (SHIROMA; MORAES; EVANGELISTA, 2002, p. 64-65).
}

Desta forma, a questão do aumento de alunos na Educação Infantil nos anos 2006 a 2011 demanda estudos e análises com 
relação aos custos e ao financiamento dessas metas. Em linhas gerais, a proposta do Plano não foi definir um parâmetro básico de custo/aluno para assegurar um ensino de qualidade, tendo em vista as necessidades de atendimento aos diversos níveis de modalidades de ensino, tampouco chegar a um valor preciso de recursos financeiros necessários de acordo com um cronograma de desembolso para o cumprimentos das metas e dos objetivos definidos pelo plano. Pinto (2002, p. 120) assinala que:

[...] o procedimento adotado no projeto aprovado foi o oposto: não se estabelece um padrão básico de custo/aluno e define-se um conjunto extremamente extenso e detalhado de metas (295 no total), sem a correspondente avaliação do respectivo impacto financeiro. $\mathrm{O}$ aspecto positivo do texto do relator foi a propositura de que os gastos públicos com educação atingisse o equivalente a $7 \%$ do PIB, ao passo que o projeto do executivo propunha $6,5 \%$ do PIB com recursos públicos e privados, o que significaria, praticamente, congelar os gastos públicos atuais com ensino, que não superam $4,5 \%$ do PIB. Contudo, este ponto positivo do texto aprovado diante do projeto do Executivo foi vetado pelo presidente e nenhum valor foi fixado.

As metas de principal impacto financeiro para $\mathrm{O}$ financiamento da Educação Infantil do texto final do PNE foram os descritos a seguir.

PNE Lei $\mathrm{n}^{\circ} 10.172 / 2001$

- Assegurar o atendimento de $30 \%$ das crianças na faixa de 0 a 3 anos e de $60 \%$ na faixa de 4 a 6 anos, em 5 anos, atingindo 50\% e 80\% nessas respectivas faixas etárias, em 10 anos, universalizando o atendimento na faixa de 6 anos e incorporando-a ao ensino fundamental que passaria a ter 9 anos de duração (não defini a parcela que caberia ao sistema público de ensino fundamental) (Meta 1). 
PARTE II - AS POLÍTICAS PÚBLICAS PARA A EDUCAÇÃO INFANTIL...

- Em 5 anos, prédios e instalação com padrões mínimos de infra-estrutura (Meta 4).

- Que, em 5 anos, $100 \%$ dos professores tenham formação de nível médio (normal) e, em 10 anos, de nível superior (Meta 5).

- Em 3 anos, $100 \%$ dos municípios com estrutura de supervisão da Educação Infantil (pública e privada) (Meta 10).

- Alimentação escolar para todas as crianças matriculadas na Educação Infantil (instituições públicas e conveniadas) (Meta 12).

- Adotar progressivamente o atendimento em tempo integral (não define prazo) (Meta 18).

- (VETADO) Atender, no Programa de Garantia de renda Mínima, em 3 anos, $50 \%$ das crianças de 0 a 6 anos que se enquadram nos seus critérios, atingindo $100 \%$ em 6 anos (Meta 22) (BRASIL, 2001, p. 43-44).

Percebe-se, diante das metas estabelecidas, a postura do Executivo em vetar as metas que viabilizariam um maior comprometimento financeiro com a educação. Todos os itens que implicariam em um aporte adicional de recursos foram vetados pelo governo FHC, caracterizando uma falta de maior comprometimento com a qualidade:

[...] a política para o setor nos anos FHC teve como pressuposto básico o postulado de que os recursos existentes para a educação no Brasil são suficientes, cabendo apenas otimizar a sua utilização, por meio de uma maior focagem nos investimentos e uma maior "participação" da sociedade (PINTO, 2002, p.125).

Essa lógica expressa uma harmonia com a ideologia neoliberal, priorizando o Ensino Fundamental em relação às outras etapas do ensino. Os recursos adicionais, nessa estratégia, 
Políticas públicas para a Educaçäo Infantil no Brasil (1990-2001)

ficam a cargo do setor privado, das parcerias com empresas e do trabalho voluntário.

\subsubsection{Referencial Curricular Nacional para a Educação Infantil (RCNEI)}

O RCNEI é um material elaborado pelo MEC para integrar a série de documentos dos Parâmetros Curriculares Nacionais para a Educação (BRASIL, 1998). Compõe o material uma coleção de três volumes, apresentando a estrutura descrita abaixo.

\section{RCNEl (1998) - Estrutura de organização do documento:}

- Um documento Introdução, que apresenta uma reflexão sobre as creches e pré-escolas no Brasil, situando e fundamentando concepções de criança, de educação, de instituição e do profissional, que foram utilizadas para definir os objetivos gerais da educação infantil e orientaram a organização dos documentos de eixos de trabalho que estão agrupados em dois volumes relacionados aos seguintes âmbitos de experiência: Formação pessoal e Conhecimento de Mundo.

- Um volume relativo ao âmbito de experiência Formação Pessoal e Social que contém o eixo de trabalho que favorece, prioritariamente, os processos de construção da Identidade e Autonomia das crianças.

- Um volume relativo ao âmbito de experiência Conhecimento de mundo que contém seis documentos referentes aos eixos trabalho orientados para a construção das diferentes linguagens pelas crianças e para as relações que estabelecem com os objetos de conhecimento: Movimento, Música, Artes Visuais, Linguagem oral e Escrita, natureza e Sociedade e Matemática (BRASIL, 1998, p. 7). 
PARTE II - AS POLÍTICAS PÚBLICAS PARA A EDUCAÇÃO INFANTIL...

$\mathrm{Na}$ análise do primeiro volume (com 103 páginas) podem-se observar os conceitos importantes que delimitam essa etapa educacional, tais como: criança, educar, cuidar, brincar, interação social, o perfil do profissional dessa área, os conteúdos e os objetivos. Constata-se que as referências bibliográficas no RCNEI são, em grande parte, as produções recentes dessa área, e muitas nem sequer foram citadas no texto do documento. Os conceitos principais estabelecidos são os descritos a seguir.

\section{RCNEl (1998) - Conceito de criança}

A criança como todo ser humano, é um sujeito social e histórico e faz parte de uma organização familiar que está inserida em uma sociedade, com uma determinada cultura, em um determinado momento histórico. É profundamente marcada pelo meio social em que se desenvolve, mas também o marca. A criança tem na família, biológica ou não, um ponto de referência fundamental, apesar da multiplicidade de interações sociais que estabelece com outras instituições sociais (BRASIL, 1998, p. 21).

Quanto ao conceito de criança, o documento traz a mesma definição apresentada anteriormente nos textos produzidos pelo COEDI (Coordenação de Educação Infantil/MEC) no período de 1993 a 1998. Nessa análise, chama a atenção a continuidade do que vinha sendo produzido pelo COEDI. Cerisara (2002) denomina esta continuidade de aparente, porque mais à frente o RCNEI expressa uma concepção semelhante à do Ensino Fundamental, desvirtuando o que propunham os estudos do COEDI e o que o referencial expõe na sua introdução, como se observa na colocação abaixo. 
Políticas públicas para a Educaçäo Infantil no Brasil (1990-2001)

\section{RCNEI (1998) - Conceito de Educar}

Educar significa, portanto, propiciar situações de cuidados, brincadeiras e aprendizagens orientadas de forma integrada e que possam contribuir para o desenvolvimento da capacidade infantil de relação interpessoal, de ser e estar com os outros em uma atitude básica de aceitação, respeito e confiança, e o acesso, pelas crianças, aos conhecimentos mais amplos da realidade social e cultural. Neste processo, a educação poderá auxiliar o desenvolvimento das capacidades de apropriação e conhecimentos das potencialidades corporais, afetivas, emocionais, estéticas e éticas, na perspectiva de contribuir para a formação de crianças felizes e saudáveis (BRASIL, 1998, p. 23, grifo nosso).

O conceito de educar apresenta uma concepção baseada em dois fatores: propiciar situações e propiciar o acesso. Isso revela a noção de que a educação acontece em apenas uma via, ou seja, no professor que educa a criança. Deixa-se de lado a concepção da criança como ser social que participa ativamente no processo educativo. A educação fica reduzida ao verbo auxiliar, denotando uma redução do ato educativo, como se o educar fosse um mero auxiliar no processo de aprendizagem. É atribuída à educação a tarefa de contribuir para a formação de crianças felizes e saudáveis. Nota-se a falta de documento que conceitue o termo feliz, e aqui se encontra atrelada à Educação Infantil a preocupação com a saúde, uma vez que no conceito é enfatizada a formação de crianças saudáveis. Está presente o caráter de uma educação compensatória, a ideia de que por meio da educação será promovida uma mudança social, com vistas a superar as defasagens, a remediar e recuperar a situação da infância. 


\section{RCNEI (1998) - Conceito de Cuidar}

[...] cuidar da criança é sobretudo dar atenção a ela como pessoa que está num contínuo crescimento e desenvolvimento, compreendendo sua singularidade, identificando e respondendo às suas necessidades. Isto inclui interessar-se sobre o que a criança sente, pensa, o que ela sabe sobre si e sobre o mundo, visando à ampliação deste conhecimento e de suas habilidades, que aos poucos a tornarão mais independente e mais autônoma (BRASIL, 1998, p. 25).

No conceito de cuidar, atribui-se ao professor a tarefa de identificar as necessidades do aluno e responder a elas, porém não está explicitado a que necessidades o autor do texto se refere. Além do mais, valoriza-se a concepção de habilidades, termo bastante presente no contexto da reforma educacional e da autonomia.

\section{RCNEI (1998) - Conceito de Interação Social}

A interação social em situações diversas é uma das estratégias mais importantes do professor para a promoção de aprendizagens pelas crianças. [...] é importante frisar que as crianças se desenvolvem em situações de interação social, nas quais conflitos e negociação de sentimentos, ideias e soluções são elementos indispensáveis. O âmbito social oferece, portanto, ocasiões únicas para elaborar estratégias de pensamento e de ação, possibilitando a ampliação das hipóteses infantis. [...] A interação permite que se crie uma situação de ajuda na qual as crianças avancem no seu processo de aprendizagem (BRASIL, 1998, p. 31-32).

A definição de interação social se refere a uma estratégia de aprendizagem, e não a uma categoria dialética, e está aqui colocada em uma concepção cognitivista. 
Políticas públicas para a educaçäo infantil no brasil (1990-2001)

\section{RCNEI (1998) - Conceito do perfil do profissional}

Em consonância com a LDB, este referencial utiliza a denominação "professor de educação infantil" para designar todos os/as profissionais responsáveis pela educação direta das crianças de zero a seis anos, tenham eles/elas uma formação especializada ou não. [...] O trabalho direto com as crianças pequenas exige que o professor tenha uma competência polivalente. Ser polivalente significa que ao professor cabe trabalhar com conteúdos de naturezas diversas que abrangem desde cuidados básicos essenciais até conhecimentos específicos provenientes das diversas áreas do conhecimento (BRASIL, 1998, p.41).

O termo polivalente relativo ao professor denota a concepção de este é o único responsável pela educação e cuidado e pelo sucesso das crianças. Ademais, o termo caracteriza uma concepção neoliberal sobre as qualidades requeridas pela sociedade capitalista para atender às novas exigências estabelecidas para a gerência da qualidade total das escolas, as quais tendem a aplicar a todas as instituições, em particular às educativas, os mesmos princípios e métodos administrativos vigentes na empresa, nos quais os fins dizem respeito à constituição de sujeitos.

\section{RCNEl (1998) - Conteúdos estabelecidos para a Educação Infantil}

Considerando-se as particularidades da faixa etária compreendida entre zero a seis anos e suas formas específicas de aprender criou-se categorias curriculares para organizar os conteúdos a serem trabalhados nas instituições de educação infantil. Esta organização visa abranger diversos e múltiplos espaços de elaboração de conhecimentos e de diferentes linguagens, a construção da identidade, os processos de socialização e o desenvolvimento da autonomia das crianças que propiciam, por sua vez, as aprendizagens consideradas essenciais. 
Esta abordagem é didática e visa a destacar a importância de se dar um tratamento apropriado aos diferentes conteúdos, instrumentalizando 0 planejamento do professor para que possa contemplar as seguintes categorias: os conteúdos conceituais que dizem respeito ao conhecimento de conceitos, fatos e princípios; os conteúdos procedimentais referem-se ao saber-fazer e os conteúdos atitudinais estão associados a valores atitudes e normas. Nos eixos de trabalho, estas categorias de conteúdos estão contempladas embora não estejam explicitadas de forma discriminada (BRASIL, 1998, p. 45-49).

Essa forma de organizar o conteúdo na Educação Infantil possui semelhanças com a forma estruturada no Ensino Fundamental. Como coloca Cerisara (2002, p. 340),

Esta forma de organização e o conteúdo trabalhado evidenciam uma subordinação ao que é pensado para o ensino fundamental e acabam por revelar a concepção primeira deste RCNEI, em que as especificidades das crianças de 0 a 6 anos acabam se diluindo no documento ao ficarem submetidas á versão escolar de trabalho. Isso porque a didatização de identidade, autonomia, música, artes, linguagens, movimento, entre outros componentes, acaba por disciplinar e aprisionar o gesto, a fala, a emoção, o pensamento, a voz e o corpo das crianças.

Outra questão relativa aos conteúdos apontada por Arce (2001) está em sua divisão em conteúdos atitudinais, procedimentais e conceituais, os quais foram inseridos sem ao menos serem citados os estudos que alicerçaram o contexto das reformas educacionais espanholas ${ }^{92}$ que definiram essas questões.

92 César Coll Salvador, professor da Faculdade de Psicologia de Barcelona na Espanha, foi responsável, juntamente com sua equipe, pelo desenvolvimento da reforma de 1990, a Renovação Pedagógica. Foi convidado no Brasil para ser consultor do MEC, entre 1995 e 1996 na elaboração dos Parâmetros Curriculares Nacionais, publicados em 1997. 
Políticas públicas para a Educaçäo Infantil no Brasil (1990-2001)

RCNEl (1998) - Objetivos estabelecidos para a Educação Infantil

Os objetivos explicitam intenções educativas e estabelecem capacidades que as crianças poderão desenvolver como consequência de ações intencionais do professor. Os objetivos auxiliam na seleção de conteúdos e meios didáticos. [...] faz-se necessário uma atuação que propicia o desenvolvimento de capacidade envolvendo aquela de ordem física, afetiva, cognitiva, ética, estética, de relação interpessoal e inserção social (BRASIL, 1998, p. 47).

Quanto aos objetivos, aos conteúdos e ao conceito de interação social, destaca-se a presença de fundamentações teóricas do construtivism, marcadas pelo reducionismo e ecletismo, uma vez que na leitura dos RCNEIs se encontram as teorias de Piaget, Vygostsky e Wallon incorporadas em uma única via do interacionismo e construtivismo (ARCE, 2001).

No segundo volume (com 85 páginas), o documento, ao tratar da proposta de formação pessoal e social, estabelece que o conhecimento e o desenvolvimento são primordiais para a construção da identidade e autonomia da criança (BRASIL, 1998, p.13). Nele se enfatiza o conceito de aprendizagem, definem-se os objetivos e conteúdos para as faixas etárias de zero a três anos e quatro a seis anos e se apresentam orientações gerais aos professores.

No terceiro volume (com 269 páginas) encontram-se estabelecidos os objetivos, conteúdos e orientações gerais para o professor nos seguintes eixos de trabalho: movimento, música, artes visuais, linguagem oral e escrita, natureza e sociedade, e matemática.

Uma questão de destaque no contexto da elaboração do RCNEI é a discussão que este provocou na finalização 
PARTE II - AS POLÍTICAS PÚBLICAS PARA A EDUCAÇÃO INFANTIL...

de sua versão preliminar. Os pareceres solicitados pelo MEC para a análise desse documento revelaram retrocessos e incoerências em relação aos conhecimentos e pesquisas anteriormente elaborados pelo COEDI. Cerisara (2003), ao fazer uma avaliação dos vários pareceres ${ }^{93}$ enviados ao MEC, assim se expressa:

\begin{abstract}
Um aspecto que causou estranhamento a vários pareceristas, refere-se à explícita falta de articulação e de continuidade entre o RCNEI e os documentos que têm sido elaborados sob a coordenação da COEDI/MEC, no período de 1993 a 1998, e que têm significado um real avanço nas relações entre esta e representantes dos centros de produção de conhecimento no encaminhamento de uma política nacional da educação infantil. [...] mesmo que o RCNEI tenha sido aperfeiçoado, melhorado, adaptado, ele continua significando uma ruptura com o que vinha sendo produzido e com o que vinha sendo defendido como a especificidade da educação infantil (CERISARA, 2003, p. 38, p. 44).
\end{abstract}

É importante compreender que o lançamento do RCNEI emergiu no contexto das reformas educacionais promovidas pelo governo FHC, através do MEC, destinadas a integrar a série Parâmetros Curriculares Nacionais, como o próprio documento ressalta. Um fato complementar que chamou a atenção foi que a publicação e a distribuição de centenas de milhares de exemplares desse documento aconteceram antes de as Diretrizes Curriculares Nacionais serem aprovadas, em

93 Ao todo, foram 26 pareceres analisados pela autora. O MEC solicitou 700 pareceres, mas chegaram até ao ministério 230 (CERISARA, 2003, p.22). Importante considerar que em fevereiro de 1998 a versão preliminar desse documento foi encaminhada a 700 profissionais ligados à área de Educação Infantil para que um mês depois fosse devolvido ao MEC um parecer sobre essa versão. A versão final foi lançada em outubro de 1998, de forma rápida, por um grupo restrito e fechado (CERISARA, 2002, p. 338). 
Políticas públicas para a Educaçäo Infantil no Brasil (1990-2001)

um momento de interesse político para futuros resultados eleitorais:

\begin{abstract}
Sabe-se que, agora, o documento estará denominado no singular - referencial -, apresentando-se como uma das perspectivas possíveis de se pensar a educação infantil. Mas o Referencial Curricular Nacional terá um grande impacto. A ampla distribuição de centenas de milhares de exemplares às pessoas que trabalham com esse nível educacional mostra o poder econômico do Ministério da Educação e seus interesses políticos, muito mais voltados para futuros resultados eleitorais do que preocupados com a triste realidade das nossas crianças e instituições. Com isso, a expressão no singular - referencial - significa, de fato, a concretização de uma proposta que se torna hegemônica, como se fosse única (KUHLMANN JÚNIOR, 2003, p. 52).
\end{abstract}

As críticas elaboradas pelos pareceristas demonstram que na versão final do RCNEI há uma comprovação de lançamento prematuro para a área, pois não houve discussões e definições por parte dos envolvidos com a Educação Infantil.

\title{
2.3.6 Diretrizes Curriculares Nacionais para a Educação Infantil (1999) - DCNEI
}

As DCNEIs representam a orientação nacional para a área da Educação Infantil na elaboração das propostas pedagógicas (BRASIL, 1999), isto é, apresentam diretrizes obrigatórias que definem os princípios norteadores que as propostas pedagógicas das instituições de Educação Infantil devem adotar e seguir, como se nota abaixo. 


\section{DCNEI (1999) - Conceito das diretrizes}

Art $2^{\circ}$ - Diretrizes Curriculares Nacionais, constituem-se na doutrina sobre Princípios Fundamentos e Procedimentos da Educação Básica, definidos pela Câmara de Educação Básica do Conselho Nacional de Educação, que orientarão as Instituições de Educação Infantil dos Sistemas Brasileiros de Ensino, na organização, articulação, desenvolvimento e avaliação de suas propostas pedagógicas (BRASIL, 1999, p.1).

Definem-se como princípios norteadores das Propostas Pedagógicas os apresentados abaixo.

\section{DCNEl (1999) - Fundamentos Norteadores para as propostas pedagógicas das instituições de Educação Infantil}

Art. $3^{\circ}$ - São as seguintes as Diretrizes Curriculares Nacionais para a Educação Infantil:

I - As Propostas Pedagógicas das Instituições de Educação Infantil, devem respeitar os seguintes Fundamentos Norteadores:

a) Princípios Éticos da Autonomia, da Responsabilidade, da Solidariedade e do Respeito ao Bem Comum;

b) Princípios Políticos dos Direitos e Deveres de Cidadania, do Exercício da Criticidade e do Respeito à Ordem Democrática;

c) Princípios Estéticos da Sensibilidade, da Criatividade, da Ludicidade e da Diversidade de Manifestações Artísticas e Culturais (BRASIL, 1999, p.1).

Ao todo, o documento das DCNEIs (BRASIL, 1999) apresenta oito diretrizes, a saber:

- A importância das instituições reconhecerem e definirem a identidade pessoal de alunos, suas famílias, professores, outros profissionais e a própria instituição;

155 
Políticas públicas para a Educaçäo infantil no Brasil (1990-2001)

- Promover a integração do educar e cuidar na proposta juntamente com os aspectos físicos, emocionais, afetivos, cognitivo/linguístico e social;

- Provimento de conteúdos básicos para a constituição de conhecimentos e valores; organizar as estratégias de avaliação por meio do acompanhamento e registros, sem objetivo de promoção ao Ensino Fundamental;

- As Propostas Pedagógicas devem ser coordenadas e avaliadas por educadores com diploma de curso de formação de professores;

- A valorização de um ambiente de gestão democrática e participativa na elaboração e concretude da proposta;

- As Propostas Pedagógicas devem possuir o objetivo de propiciar condições para o funcionamento das estratégias educacionais, bem como a execução, avaliação e aperfeiçoamento (BRASIL, 1999, p. 2).

As DCNEIs estabelecem normas para a elaboração dos projetos pedagógicos para a Educação Infantil. A valorização dos conteúdos básicos está presente no art. 3º inciso IV: "[..] provimento de conteúdos básicos”. Nelas se observa também a presença da conceituação dos pilares estabelecidos no documento da Unesco Educação: um tesouro a descobrir, conhecido como Relatório Jacques Delors (BRASIL, 1999, p.1).

As recomendações do Relatório Jacques Delors (DELORS,1998) que aparecem expressas nas DCNEIs representam as reflexões e propostas que conduziram as políticas educacionais e o processo de reforma da educação para o século XXI no Brasil e em outros países signatários. No documento (DELORS, 1998, p.19) a educação é definida como "[...] uma das chaves de acesso ao século XXI [...] vem dar resposta ao desafio de um mundo em rápida transformação”. O Relatório estabelece como base dessa educação quatro pilares: 


\begin{abstract}
Aprender a conhecer, combinando uma cultura geral, suficientemente vasta, com a possibilidade de trabalhar em profundidade um pequeno número de matérias. O que também significa: aprender a aprender, para beneficiar-se das oportunidades oferecidas pela educação ao longo de toda a vida. Aprender a fazer, a fim de adquirir, não somente uma qualificação profissional mas, de uma maneira mais ampla, competências que tornem a pessoa apta a enfrentar numerosas situações e a trabalhar em equipe [...] Aprender a viver juntos desenvolvendo a compreensão do outro e a percepção das interdependências - realizar projetos comuns e preparar-se para gerir conflitos - no respeito pelos valores do pluralismo, da compreensão mútua e da paz. Aprender a ser, para melhor desenvolver a sua personalidade e estar à altura de agir com [...] maior capacidade de autonomia, de discernimento e de responsabilidade pessoal (DELORS, 1998, p.101102, grifo nosso).
\end{abstract}

A intenção da Unesco ao apresentar suas orientações neoliberais no Relatório é claramente expressa pela agência: "[...] Esta perspectiva deve, no futuro, inspirar e orientar as reformas educativas, tanto em nível da elaboração de programas como da definição de novas políticas pedagógicas" (DELORS, 1998, p.102).

Ao concluir as análises sobre as políticas públicas para a Educação Infantil nesta parte, ressalta-se que entendêlas isoladamente a partir da dinâmica do desenvolvimento capitalista não foi o objetivo aqui proposto. Nos pressupostos históricos da Educação Infantil percebe-se que o atendimento à primeira infância representou, no início, uma ideologia discursiva bastante presente que considerava a infância o futuro promissor para a nação brasileira. Apesar dos percalços sempre presentes, a expansão das relações internacionais proporcionou o crescimento das instituições, e após 150 anos de existência, 
com uma organização educativa diferenciada e uma legislação educacional considerada instrumento de ação avançado, ainda resta um longo caminhar para que a Educação Infantil como um direito se concretize na prática.

Carrega-se ainda a crença em um futuro promissor alavancado pela educação. Acredita-se, ideologicamente e de forma estrategicamente determinada, que investir na infância traz resultados para um desenvolvimento sustentável da economia, Tal ideia gera ações baseadas na concepção de que a criança é o futuro da Nação e de que dela provém a esperança de dias melhores. Neste sentido, aos futuros cidadãos deve-se proporcionar uma formação adequada, a fim de garantir o sucesso da economia. Não se vê nesse modo de pensar a conotação de transformação, mas a de alimentação e sustentação, termos definidores da palavra sustentável ${ }^{94}$, tão de gosto das agências internacionais.

Nos documentos analisados destacaram-se as recomendações políticas contidas nos documentos dos organismos internacionais que aparecem nos documentos oficiais do MEC promulgados ao longo da década de 1990 e elaborados segundo as orientações políticas mundiais para a

94 Segundo o dicionário Aurélio, o termo Sustentável significa: Que se pode sustentar. E Sustentar tem a definição de: 1) segurar por baixo, servir de escora a, impedir que caia, suportar, apoiar. 2) Afirmar categoricamente. 3) Ratificar, reafirmar, confirmar. 4) fazer face a; resistir a; sustar. 5) Conservar, mater. 6) Alimentar física ou moralmente. 7) Prover de víveres ou munições. 8) Impedir a ruína ou a queda de; amparar. 9) Dar ânimo a; animar. 10) Proteger, favorecer, auxiliar. 11) Sofrer com resignação, com firmeza; aguentar. 12) Defender com argumentos, com razões. 13) Estimular, incitar, instigar. 14) Pelejar a favor de. 15) Ser contrário, opor-se a. 16) Conservar a mesma posição; suster-se, equilibrar-se. Porém, nesta pesquisa o conceito de sustentável não se apoia nas definições neoliberais, que veem na educação o elo estratégico para a sustentação da economia, de sentido reacionário e mantenedor. Considera-se que a sustentabilidade de uma sociedade é determinada pelo seu modo de produção. 
Educação Infantil. Entre essas recomendações desatacam-se as contidas no quadro abaixo.

\begin{tabular}{|c|c|c|c|}
\hline \multicolumn{4}{|c|}{$\begin{array}{l}\text { Recomendações políticas á Educação Infantil na década de 1990: algumas } \\
\text { categorias }\end{array}$} \\
\hline UNESCO & CEPAL & BM & BID \\
\hline $\begin{array}{l}\text { - Direito Humano } \\
\text { - Qualidade } \\
\text { - Aprender a } \\
\text { aprender, a } \\
\text { fazer, a conviver } \\
\text { - Educação para } \\
\text { o trabalho } \\
\text { - Desenvolvi- } \\
\text { mento } \\
\text { sustentável } \\
\text { - Expansão e } \\
\text { Melhoria } \\
\text { - Focalização } \\
\text { à Educação } \\
\text { Básica primária, } \\
\text { á meninas, aos } \\
\text { pobres } \\
\text { - Equidade }\end{array}$ & $\begin{array}{l}\text { - Equidade } \\
\text { - Transformação } \\
\text { produtiva } \\
\text { - Desenvolvimento } \\
\text { sustentável } \\
\text { - Focalização à } \\
\text { pobreza } \\
\text { - Educação para a } \\
\text { competitividade }\end{array}$ & $\begin{array}{l}\text { - Desenvolvimento } \\
\text { Sustentável } \\
\text { - Focalização à } \\
\text { pobreza } \\
\text { - Capital Humano } \\
\text { - Equidade } \\
\text { - Qualidade } \\
\text { - Descentralização }\end{array}$ & $\begin{array}{l}\text { - Focalização à } \\
\text { pobreza } \\
\text { - Cuidado Infantil } \\
\text { - Desenvolvimento } \\
\text { Sustentável } \\
\text { - Focalização à } \\
\text { Educação Básica } \\
\text { - Qualidade } \\
\text { - Descentralização } \\
\text { - Aumento } \\
\text { produtivo } \\
\text { - Responsabilidade } \\
\text { - Social }\end{array}$ \\
\hline
\end{tabular}

$\mathrm{Na}$ análise dessas recomendações políticas, as quais serão tratadas neste trabalho como categorias discursivas ${ }^{95}$, observouse que elas estiveram presentes nos documentos oficiais do MEC, como mostra o quadro a seguir.

95 São enunciados que fazem parte de uma série ou de um conjunto que desempenha um papel específico no meio de todo o texto/contexto político-econômico. Apoiam-se nessa amplitude, mas ao mesmo tempo se distinguem, pois possui objetivo próprio, se refere a uma condição material que possui significado (BRANDÃO, 1996). Neste trabalho, consideram-se as categorias como produtos históricos determinados, pois expressam as contradições dos interesses políticos e econômicos. Todavia, as análises dessas categorias permitem a compreensão das políticas educacionais no contexto da mundialização da economia, do livre-mercado, no qual os direitos sociais são descartados pelo culto da produção e do consumo. 

PARTE II - AS POLÍTICAS PÚBLICAS PARA A EDUCAÇÃO INFANTIL...

As categorias evidenciadas tanto nos documentos dos organismos internacionais quanto nos documentos oficiais do MEC serão discutidas na próxima parte concomitantemente com a análise das categorias presentes nos textos veiculados na década de 1990 pela revista Nova Escola e pela Revista Criança que trataram da temática política para a Educação Infantil.

As políticas relacionadas à Educação Infantil estão repletas de contradições. Percebe-se que a prioridade dada ao Ensino Fundamental favorece uma concepção de educação fragmentada, em que se prioriza uma etapa em detrimento da outra, gerando descaso para com a Educação Infantil e desinteresse pela educação. Isso favorece a permanência da herança assistencial na Educação Infantil, uma vez que a área ainda é carente de definições ${ }^{96}$ no âmbito pedagógico, como também causa disputas internas.

O discurso da gratuidade na Lei é uma falácia óbvia, pois os serviços prestados pelo Estado são pagos com recursos provindos dos impostos, taxas e contribuições que o município arrecada. Fonseca (2001) menciona que o argumento da prioridade do Ensino Fundamental é uma maneira de justificar a proposta de duplo pagamento no ensino público.

A equidade, considerada um princípio de estratégia política, é recorrente em todos os documentos analisados. No PNE, as metas de expansão das matrículas, além de representarem um impacto financeiro, são contraditórias, pois nem todos têm

96 Definição de uma Pedagogia específica para a Educação Infantil, que implica as discussões quanto à formação e à capacitação do professor, à avaliação, ao planejamento, ao currículo, ao ensino, ao cuidado e a outros aspectos. 
Políticas públicas para a Educaçäo Infantil no Brasil (1990-2001)

o acesso ao ensino. Nestas análises se encontram contradições que refletem a presença de um Estado descentralizador e cada vez menos presente e cujas ações favorecem apenas o capital, a classe dominante. 